NBER WORKING PAPER SERIES

\title{
TECHNOLOGICAL CHANGES AND EMPLOYMENT OF OLDER MANUFACTURING WORKERS IN EARLY TWENTIETH CENTURY AMERICA
}

\author{
Chulhee Lee \\ Working Paper 14746 \\ http://www.nber.org/papers/w14746
NATIONAL BUREAU OF ECONOMIC RESEARCH
1050 Massachusetts Avenue
Cambridge, MA 02138
February 2009

I thank Dora Costa, Alexander Field, and the participants in the ASSA Meetings, Hosei Institute of Aging Workshop, NBER Cohort Studies Meeting, and SNU-Tokyo University Joint Conference for their helpful comments and suggestions, and J. Kwon, S. Lee, Y. Kim, and D. Oh for their research assistance. This study is supported by the National Institute of Aging, the National Institutes of Health(PO1 AG10120). The views expressed herein are those of the author(s) and do not necessarily reflect the views of the National Bureau of Economic Research.

NBER working papers are circulated for discussion and comment purposes. They have not been peerreviewed or been subject to the review by the NBER Board of Directors that accompanies official NBER publications.

(C) 2009 by Chulhee Lee. All rights reserved. Short sections of text, not to exceed two paragraphs, may be quoted without explicit permission provided that full credit, including (C) notice, is given to the source. 
Technological Changes and Employment of Older Manufacturing Workers in Early Twentieth Century America

Chulhee Lee

NBER Working Paper No. 14746

February 2009

JEL No. J26,J64,J81,N31

\begin{abstract}
This study explores how technological, organizational, and managerial changes affected the labor-market status of older male manufacturing workers in early twentieth century America. Industrial characteristics that were favorably related to the labor-market status of older industrial workers include: higher labor productivity, less capital- and material-intensive production, a shorter workday, lower intensity of work, greater job flexibility, and more formalized employment relationship. Technical innovations that improved productivity often negatively affected the quality of the work environment of older workers. These results suggest that the technological transformations in the Industrial Era brought mixed consequences to the labor-market status of older workers. On one hand, technical and organizational modifications improved the elderly workers' employment prospect by raising labor productivity, diminishing hours of work, and formalizing employment relations. On the other hand, some types of technical innovations, which are characterized by additional requirements for physical strength, mental agility, and ability to acquire new skills, forced older workers out of their jobs. Since the pace and nature of technical change considerably differed across industries, and possibly across firms within the same industry, the labor-market experiences of individual older workers should have been highly heterogeneous.
\end{abstract}

\author{
Chulhee Lee \\ Department of Economics \\ Seoul National University \\ Kwanak-ro 599, Kwanak-gu \\ Seoul 151-742, S. KOREA \\ chullee@snu.ac.kr
}




\section{Introduction}

A sharp decline in the labor market activity of the elderly male population is regarded as one of the most significant labor market changes in America in the past century. In 1880, nearly four out of five men aged 65 and older were gainfully employed in the United States (Moen 1987, Costa 1998). Today, less than 20\% participate in the labor force. Many economists have attributed the decline to the factors that influence labor supply decisions of older persons. ${ }^{2}$ In particular, the implementation and expansion of social insurance programs such as the Social Security has been regarded as the major cause of the long-term decline in the labor force participation rate (LFPR, hereafter) among older men. ${ }^{3}$ In current literature on this issue, however, it is often neglected that nearly half of the decline in the economic activity of older men since 1880 happened before the Social Security Act was passed. As will be surveyed below in detail, it is not entirely clear what made the elderly male workers leave the labor force earlier than before, even prior to the rise of the welfare state.

According to contemporary accounts, the features of the workplace such as production technology, managerial practices, work organization, employment relations, and labor market conditions played more important roles in determining the timing of retirement in the past than they do today. For instance, it was widely believed that the increased speed and intensity of work forced elderly workers out of labor market either by diminishing their relative productivity or by making their employment more costly (Squier 1912, Epstein 1928, Graebner 1980). Some claimed that the decline in job flexibility, often resulting from changes in work organization and workplace management, made it difficult for elderly employees to make gradual adjustments in response to the influences of aging. As

${ }^{2}$ Notable exceptions are studies by Hurd (1996) and Hurd and McGarry (1993) who suggested that a job's flexibility and financial aspects were important determinants of retirement decisions.

${ }^{3}$ It has been suggested that the Old Age Assistance (OAA) was the main underlying force behind the sharp decline in the LFPR of older men during the 1930s (Gratton 1988, Parsons 1991). Many have attributed the decline in the LFPR of older males from the 1960s to the increase in real Social Security benefits (Boskin 1977, Parsons 1980, Hurd and Boskin 1984). Recent comparative studies have concluded that measures of work disincentives arising from old-age pension programs were strongly related to the size of labor-market activity of older males around the world (Gruber and Wise 1999, 2004). Although there is considerable disagreement in the literature as to the magnitude and direction of the effect of Social Security on labor supply (Krueger and Meyer 2002), it would be hard to deny that Social Security still remains probably the single most important explanation for the longterm decline in the LFPR of older males in the United States. 
technological advances made formal education and on-the-job training more crucial for improving productivity, employers increasingly hesitated to hire older workers probably because their skill sets have rapidly become obsolete and training them would pay off little. Some of the adverse impacts of industrial changes on the labor-market status of older workers could have been mediated by deteriorating health.

The purpose of this article is to study how changes in technology and managerial practices affected the employment of older manufacturing workers in the early twentieth century United States. More specifically, the article investigates how the probabilities of long-term unemployment in 1910 and retirement between 1900 and 1910 were related to the different features of the industry in which the older worker was employed, such as industryspecific labor-market conditions, size of establishment, labor productivity, input mix, hours of work, use of electric power, and employment structure. For this purpose, the Integrated Public Use Micro Samples (IPUMS) of the 1910 census and a longitudinal sample of Union Army veterans that have been linked to industry-level data compiled from the 1899 and 1909 manufacturing census reports were utilized.

This article suggests that the incidence of long-term unemployment among older males considerably differed across industries. Industrial characteristics that were related to more favorable labor-market status of older industrial workers include: higher labor productivity, less capital- and material-intensive production, a shorter workday, lower intensity of work, greater job flexibility, and more formalized employment relationship. Technical innovations that improved productivity often affected the quality of work environment of older workers. Based on the results, it is argued that the technological transformations in the Industrial Era brought mixed consequences to the labor-market status of older workers, and that the labor-market experiences of individual older workers were highly heterogeneous.

The study may add new quantitative evidence to the literature regarding the labormarket status of older workers and the nature of retirement in the past. Relatively, there are abundant micro-level studies pertaining to long-term unemployment and retirement of older male workers in the early twentieth century (Margo 1993, Moen 1994, Carter and Sutch 1996, Costa 1998, Lee 1998b, 1999, 2002, 2005). However, this study is distinct from previous works because it examines the roles played by industrial features, together with personal characteristics. This paper may also help understand why the LFPR of older men 
declined prior to the Social Security era. Though not directly addressed in the present paper, the study could offer implications on the issue of how the on-going technological changes, such as the advances in IT technology (Friedberg 2001) and shifts in the corporate structure and work organization will change the labor-market activity of older workers.

\section{Industrialization and Old Labor}

The United States experienced rapid maturing and deepening of industrialization from the late nineteenth to early twentieth century. This period is often referred to as the Industrial Era. As a consequence, the proportion of the labor force employed in agriculture greatly shrank during the period. It is well documented how the change in the industrial structure affected the employment of older Americans during the period. It has been widely acknowledged in both contemporary and historical studies that self-employed jobs, farming in particular, were more favorable for the employment of older workers than wage jobs because of their greater flexibility. The self-employed can remain in the workforce until old age by adjusting their work efforts in accordance with changing health, preference, and economic need. This is similar to the condition in the early twentieth century. ${ }^{4}$

This reasoning led early studies on the older labor force to a conclusion that the decline of agriculture had brought a decline in the labor market involvement of older men (Durand 1948, Long 1958, Bancroft 1958). Recent quantitative evidence has confirmed that sectoral shifts that occurred between 1880 and 1940 substantially decreased the overall LFPR of older males in the United States. Lee (2002) has estimated that the decrease in the labor force employed in farming accounted for nearly a quarter of the decline in the LFPR of men aged 60 and older between 1880 and 1940. Lee (2005) has suggested that industrialization was responsible for growth of the sectors which brought about the strong pressure on old age employment.

Although there is still much to be learned, evidence from previous studies offers

\footnotetext{
${ }^{4}$ Quinn, Burkhauser, and Myers (1990) found that the majority of older self-employed workforce either reduced their work hours on the career job or became part-time workers, while wage or salary workers mainly left the labor force. In the early twentieth century United States, self-employed farmers were much less likely to retire than non-farm wage earners (Lee 2002). It has been reported that gradual retirement was a possible option for self-employed farmers because they were able to reduce the hours and intensity of their work by adjusting acreage and crop-mix or by adopting mechanization (Pedersen 1950).
} 
some idea about how the labor-market status of older workers varied across different occupations and by how much the shifts in industrial structure decreased the LFPR of older males. However, the reasons that produced the observed differences in the labor-market experiences of older workers across different sectors are not well understood. More significantly, very little is known about what caused the within-sector decline in the labormarket activity, which was more important than the impact of sectoral shift in explaining the decrease in the LFPR of older men. In particular, it is crucial to understand what happened within the non-agricultural sector because the rise in the probability of retirement in this sector accounted for a larger proportion of the overall decline in the LFPR of older males between 1880 and 1940 (Lee 2002).

The rise in retirement incomes is a possible explanation for the decline in the economic activity of older men within each sector. Costa (1998) has reported that $90 \%$ of the decline in the LFPR of older males between 1900 and 1930 could be attributed to secularly rising incomes. Carter and Sutch (1996) have suggested that many men in early twentieth century America planned their retirement based on wealth accumulation. In support of this view, Gratton (1996) has offered that earnings of elderly workers substantially increased between 1890 and 1950 both in absolute and relative values in comparison with the earnings of younger employees.

The rise in incomes perhaps played a significant role in diminishing the average age of retirement. In particular, wealthier individuals in the past may have voluntarily left their jobs in order to enjoy leisure as many ordinary people do today. However, it is likely that retirement in the past was more forced than it is today; and retirement decisions in the preSocial Security era were perhaps influenced more strongly by demand-side factors. A study of longitudinal data of Union Army veterans has suggested that long-term unemployment of older male workers in 1900 greatly reduced their chances of remaining in the labor force by 1910 (Lee 1998b). Another study from the same source has shown that men who had better occupations in terms of economic and work conditions in 1900 were less likely to retire by 1910 than were those with poorer jobs, suggesting that retirement in the past was perhaps more forced than voluntary (Lee 2005). Analyses of the early cost of living surveys and censuses have indicated that older non-participants in the labor market were much poorer than active workers of a similar age, and that the support of children was no longer an important means of old-age security by the early twentieth century (Lee 2004). 
Another possible explanation for the rise in retirement of the non-agricultural population is technological change. Of course, this is not necessarily inconsistent with the income hypothesis introduced above. Over the late nineteenth and early twentieth centuries, the U.S. economy went through the so-called 'Second Industrial Revolution,' characterized by growth of large modern firms, emergence of new products, power sources, technologies, and huge transformation of the industrial structure (Chandler 1977, 1990). It was during this period that scientific knowledge began to be systematically applied to industrial technology, mass production methods spread, and knowledge of scientific management was adopted in workplaces. The technological changes of that era were arguably the most critical in all of modern times in terms of the magnitude of the long-run impact on productivity and human well-being - even more important than the 'First Industrial Revolution' or the 'Information Technology Revolution' in the recent decades (Gordon 2000).

Contemporary observers believed that elderly workers were reduced to "industrial scrap heap," victimized by the consequences of technological changes. According to these accounts, elderly industrial workers were subject to a greater probability of job loss and forced retirement due to unfavorable work conditions, such as less flexibility and greater intensity of work (Squier 1912, Epstein 1928). A well-known anecdote is the exodus of the elderly operatives from the printing industry upon the adoption of a faster machine (Graebner 1980). It has also been suggested that industrialization brought greater disadvantages in employment associated with aging, such as more serious age discrimination and greater importance of job-specific skills that inhibited the hiring and training of older workers (Slichter 1917, Haber 1983). ${ }^{5}$

A case study of the American shoe industry has described how the mechanization of production diminished the flexibility of the work and the advantages of experienced workers as follows:

The machine ended worker control over their time; factory discipline involved far more than fixed hours for starting and stopping the workday and taking meals. The flow of work through the factory was tightly scheduled, and each step was a

\footnotetext{
${ }^{5}$ There are abundant anecdotes about the doomed fate of older workers outside the manufacturing sector. Greabner (1980) has noted that between 1900 and 1930 older salesmen were pushed out of their jobs, being criticized for their inability to adopt the method of modern corporation or to adapt to a changing economic and technological environment (pp. 45-46). It is well documented that it was difficult for aged railroad operatives in transportation to continue to work because of the great hazard and increased intensity of their job (Squier 1912, 109).
} 
carefully regulated part of the whole production process. Workers had to be at their machine performing their tasks and no longer controlled the pace of flow of work. .... The fragmentation of tasks and their mechanization greatly reduced the length of time it took to train a worker..... This separation was so complete that even an experienced machine operative was unproductive if put on another machine until he had gone through the same training period as a new hand. ${ }^{6}$

\section{Conceptual Framework}

The probabilities of long-term unemployment and non-participation in the labor market at older age are employed in this study as measures of the labor market status of elderly workers in the early twentieth century. The rationale for using these measures will be discussed below. The study demonstrates how these measures of labor market status are affected by changes in the broadly-defined technology including various industry-specific characteristics of production technology, work organization, managerial practices, and so on. These measures are denoted as $T$. According to the standard search model of unemployment, the length of job search of an unemployed man would depend on the relative size of his reservation wage (denoted $\left.W_{R}\right)$ and the market wage offered to him $(W)$. The market wage $W$ is assumed to be determined by the worker's human capital (represented by a vector of personal characteristics, denoted $X$ ), the average labor productivity of the industry (denoted $A$ ) that is a function of $T[A(T)]$, and labor- and product-markets conditions of the industry in which the worker is employed $(Z)$. Market wage offered in a particular industry can then be given as:

(1) $\quad W=W[X, Z, A(T)]$

The study offers three hypotheses. First, an older worker's reservation wage $\left(W_{R}\right)$ is determined by his or her economic status such as demand for and provision of non-labor incomes, represented by personal characteristics $(X)$ and the quality of matching between the job and the worker $(\theta)$. Second, the quality of matching is determined by the discrepancy between the amounts of work effort such as hours and intensity of work required by the worker's job (denoted by $\bar{E}$ ) and the desirable amount of work efforts that the worker would

${ }^{6}$ Mulligan, Jr. (1981), p. 63. 
choose under a situation where there are no restrictions (denoted by $E_{i}$ ). Third, the former $(\bar{E})$ is determined by technology $(T)$ and industry-specific labor-market condition $(Z)$, and that the latter $\left(E_{i}\right)$ is determined by the preference and productivity of the worker, captured by $X$. Under these assumptions, the reservation wage of the older worker can be written as:

$$
W_{R}=W_{R}[X, \theta(X, T, Z)]
$$

This specification of the reservation wage is based on contemporary claims that it became increasingly costly for older workers to keep working as the speed and intensity of work increased beyond their physical and mental capacities owing to technological changes.

The probability of long-term unemployment (denoted $P_{U}$ ) depends on the difference between $W_{\mathrm{R}}$ and $W$, as represented by the following equation:

$$
P_{U}=P_{U}\left[W_{R}\{X, \theta(X, T, Z)\}-W\{X, Z, A(T)\}\right]
$$

In this model, a variation in $T$ would affect $P_{\mathrm{U}}$ through two different pathways, namely, by altering the quality of the matching between the job and the work $(\theta)$ and by changing the size of labor productivity of the industry $(A)$, as represented by the following equation:

(4) $\quad \frac{\partial P_{U}}{\partial T}=\frac{\partial P_{U}}{\partial W_{R}} \frac{\partial W_{R}}{\partial \theta} \frac{\partial \theta}{\partial T}-\frac{\partial P_{U}}{\partial W} \frac{\partial W}{\partial A} \frac{\partial A}{\partial T}$

These two effects will be referred to as "the matching effect" and "the productivity effect," respectively. The matching effect in this model captures how technical innovations in production or organization affect an older worker's labor-market status by transforming his work environment and, as a consequence, changing the quality of the matching between the worker's characteristics (such as capacity and preferences) and the requirements of his job (length, intensity, and flexibility of work).

The purpose of offering this model is simply to illustrate that technical change could affect the employment of older workers through various pathways other than productivity 
change, and that the directions of these effects could be different. Therefore, the matching effect might be interpreted more broadly than as specified above, even with different names. This effect might capture how a newly-adopted technology alters the productive efficiency of older workers relative to that of the younger ones, whereas the productivity effect shows how it changes overall productivity of the industry. In this model, a decline in employment of older workers produced by a change in relative productivity would be identified as the matching effect.

Suppose the measures of $T$ are included in a reduced-form regression model, such as the equation given below:

$$
P_{U}=\alpha_{1}+\beta_{1} X+\gamma_{1} Z+\lambda_{1} T+\varepsilon_{1}
$$

Then, the result of a regression based on equation (5) will provide an estimate of the coefficient for $T$ in which the two terms in equation (4) are mixed. If a change in technology increased labor productivity, but diminished the quality of matching, the estimated total effect of $T$ on $P_{\mathrm{U}}$ should be smaller than its partial effect on $P_{\mathrm{U}}$ through changing $\theta$, because the two countervailing effects cancel out.

The empirical strategy employed by the study is to focus on the effect of technological change on the quality of matching by employing the following regression model.

$$
P_{U}=\alpha_{2}+\beta_{2} X+\gamma_{2} Z+\kappa_{2} A+\lambda_{2} T+\varepsilon_{2}
$$

Since a measure of industry-specific labor productivity $(A)$ is included in the regression, the coefficient for $T\left(\gamma_{2}\right)$ will only represent the matching effect, holding any change in productivity caused by the change in $T$ constant. The productivity effect can be estimated by subtracting the matching effect from the total effects $\left(\gamma_{1}-\gamma_{2}\right)$.

The above model of unemployment can be applied to a study on retirement with very little modifications. Similar to the case of a job search, individuals would compare the value of retirement (that is determined by non-labor incomes and the quality of matching) and the market wage offered to them. Thus, this study will virtually use the same 
specification and method in analyzing both the probabilities of long-term unemployment and retirement.

\section{Data}

To study how technical change affected the labor-market activity of older workers, it would be desirable to use firm-level data that contain information on both the technological characteristics and employment status of workers employed in each firm. Unfortunately, no such data are currently available for the period this study is looking into. This data limitation is circumvented by matching micro samples of population censuses (which provide information on labor-market status of individuals) with published manufacturing census reports (which offer average statistics on various technological and managerial characteristics of each industry), as will be explained below. Of course, it is not completely satisfactory to rely on industry-level analyses, ignoring differences across firms within each industry. However, if industries are classified into reasonably narrow categories, as in this study, the between-industry variations in technological characteristics are likely to capture a large fraction of the overall variations.

\subsection{Published Manufacturing Censuses of 1899 and 1909}

Measures of industry-specific technological characteristics have been constructed from the published manufacturing census reports of 1899 and 1909. These volumes provide various average statistics for each manufacturing industry. ${ }^{7}$ The method of classifying industries, and the contents and definitions of statistics differ between census years. The entire manufacturing sector is classified into 350 industries in the 1899 manufacturing census report, and into 260 industries in the 1909 report.

To connect these original industry-level data sets to micro samples of population censuses, the industries in the manufacturing censuses have been reclassified according to the industry coding schemes of the 1950 population census..$^{8}$ The 1950 census classifies

\footnotetext{
7 These statistics include the number of establishments, percentage of a particular type of ownership (e.g. shares of corporations and partnerships), number of employees by age, sex, and type of work, size of capital investments, value of products, amount of expenses on each type of input, amount of energy used by source, amount of wages paid out, and prevailing hours of work, among others.

${ }^{8}$ The classification of each specific industry was determined based on the full list of industries and
} 
industries more broadly than the published manufacturing census reports. 9 Accordingly, multiple industries in the manufacturing censuses have been combined into a single category and classified as the same industry in the 1950 population census. These methods of industry reclassifications for the 1909 manufacturing census are reported in Table A-1 of the Appendix. $^{10}$

In merging multiple manufacturing-census industries into a broader category, the sum (in the case of the total amount or number) or the weighted average (in the case of the mean or percentage) of each variable has been computed and assigned to the industrial category. In these computations, the number of wage earners employed in each industry was used as its weight, because the major purpose of this study is to examine the labor-market experiences of workers. As a consequence of this merging process, the original 260-industry dataset, compiled from the 1909 manufacturing census, was transformed into a new dataset composed of 56 more broadly classified manufacturing industries. Similarly, the original 350-industry dataset, drawn from the 1899 manufacturing census, was reshaped into a dataset containing 60 industries.

\subsection{IPUMS of the 1910 Census}

To study how the technological characteristics of a particular industry affected the probability of long-term unemployment of the workers employed in the industry, the industry variables drawn from the published 1909 manufacturing census have been linked to the IPUMS of the 1910 census (Ruggles and Sobek 1998). The 1910 census was the first to report information on both industry and the length of unemployment of individuals. The empirical analyses were based on a sample of 4,549 male manufacturing workers aged 45 and older. Where the industry variables were utilized, the sample was further restricted to those who were employed in the 56 manufacturing industries covered by the matched dataset.

their codes as reported in the 1950 population census (U.S. Bureau of the Census 1950).

9 In the 1909 manufacturing census, for example, "clothing, horse," "clothing, men's buttonholes," "clothing, men's, including shirts," "clothing, women's," and "corsets" are all separate industries, whereas the 1950 population census classifies all these industries into a single category, namely, "apparel and accessories."

${ }^{10}$ The methods of industry reclassifications for the 1899 manufacturing census, not reported in this paper, can be obtained from the author upon request. 


\subsection{Longitudinal Sample of Union Army Veterans}

A longitudinal sample is needed for studying the probability of retirement. For this purpose, a sample of white Union Army veterans who had been linked to the 1900 and 1910 censuses, as well as military, pension, and surgeons' medical records have been matched to the industry-level datasets explained above. Considering the age distribution of individuals included in the data (the mean age of the veterans in 1900 was about 58), the Union Army sample linked to the 1900 and 1910 population censuses should be suitable for examining retirement patterns.

In using this sample, a difficulty arose. The 1900 population census did not provide information on the industry in which a given person was employed. However, occupational descriptions recorded in the census can be used for the identification of the industry that the majority of the individuals in the sample was employed in. ${ }^{11}$ By exploiting this information, the three-digit 1950 industry codes for 6,699 veterans out of 8,469 men with non-missing occupational titles was determined. Of these veterans, 793 men (12\% of the sample) were employed in a manufacturing industry. This sample was further restricted to men who were linked to the 1910 census and who were gainfully employed in 1900.

\section{Industrial Differences in Long-Term Unemployment of Older Workers}

The long duration of unemployment has been cited as one of the major indicatives of the fragile labor market status of older workers in the early twentieth century. Previous studies have suggested that though older workers were less likely to be unemployed than younger workers, they had greater difficulty locating new jobs once laid off (Slichter 1919, Keyssar 1986, Margo 1993). ${ }^{12}$ Deteriorating physical strength and health, obsolete skills and knowledge, and lack of formal education as compared with their younger cohorts are some of the potential factors that may have limited employment opportunities for elderly workers. In addition, formal or informal discrimination against elderly workers made it difficult for

\footnotetext{
11 To take some examples, there are occupational titles such as "paper manufacturers," "works and cigar maker," "brakeman for railroad company," "hat factory," "in boot factory," and "works for boot factory," from which an industrial classification can be inferred.

${ }^{12}$ Unemployment around the turn of the twentieth century was predominantly involuntary for both young and old workers. According to the surveys conducted in the late nineteenth and early twentieth century, the primary cause of lost times was lay-offs, followed by sickness and accidents (Lauck and Sydenstricker 1917, Lee 2005).
} 
them to find new jobs. ${ }^{13}$

Long-term unemployment, often defined as being unemployed for six months or longer during a given year, has also been acknowledged as a major reason for leaving the labor force in the early twentieth century. Margo (1993) has reported that long-term unemployment among the elderly circa 1900 was an intermediate step toward nonparticipation. Lee (1998b) has reported that elderly men who were unemployed six months or more in 1900 were more likely to be out of gainful employment ten years later. Lee (2005) has suggested that older workers were more likely to leave their job between 1900 and 1910 if initially employed in an occupation in which the relative incidence of longterm unemployment was higher. In the light of these results, a greater probability of longterm unemployment among older workers in the early twentieth century may be regarded as indicative of a greater pressure toward leaving the labor force.

Table 1 presents the percentage of manufacturing workers in the IPUMS of the 1910 census who were unemployed for 24 weeks or more during the 1910 census year, separately for prime-age workers (aged 25 to 44) and older employees (aged 45 and older). Men aged 45 and older were classified as "older workers," on the basis of the contemporary accounts that many industrial workers in the early twentieth century began to face various disadvantages in employment associated with aging from their mid-forties. The 1910 population census did not report the weeks of unemployment for a fraction of individuals. Hence, the full sample was used for the computation, with the assumption that the individuals who did not report the weeks of unemployment were not the long-term unemployed. ${ }^{14}$ The 56 manufacturing industries were grouped into 17 broader industrial categories for this

\footnotetext{
${ }^{13}$ Ransom and Sutch (1995) found that the days lost due to illness sharply increased with age after fifty-five among both farm and industrial workers. With regard to the roles of education and skills, Gratton (1986) has suggested that clerks in turn-of-the-century Boston were predominantly young men because younger cohorts had more education and were more likely to be native born and speak English well without accents. In the early twentieth century, many firms, especially large corporations, adopted a policy of not hiring anyone over some stated maximum age, the limit being 45 years or sometimes, even lower (Durand 1948, 114-116, Long 1958, 116-171).

14 According to the result related to the pattern of transition in labor-market status between 1900 and 1910 , older men with no related information on the months of unemployment in 1900 were more similar to persons who did not experience unemployment than to the long-term unemployed (Lee 1996). It is thus likely that the majority of persons with no related information on the weeks of unemployment were not the long-term unemployed.
} 
computation. $^{15}$

The absolute incidence of long-term unemployment for older workers (column 3 of Table 1) is not a completely appropriate index of disadvantages in the labor market associated with aging. It is well documented that fluctuations in demand for labor, especially those resulting from seasonality and industry-specific business cycles, were important causes of long-term unemployment for both young and old workers during the period under study. In this respect, it would be sensible to look at a relative measure of long-term unemployment of the older workers in comparison with prime-age workers in the same industry. ${ }^{16}$ Accordingly, the final column of Table 1 offers the ratio of the incidence of long-term unemployment among males workers aged 45 and older to that among men aged 25 to $44 .{ }^{17}$

The result reported in Table 1 shows that the incidence of long-term unemployment among older manufacturing workers considerably differed across industries even within the manufacturing sector. The probability of being unemployed for 24 weeks or more in 1910 was particularly high, both absolutely and relatively, among older workers employed in the textile, lumber and wood working, printing, primary metals, and fabricated metals industries. In contrast, older workers were much less likely to experience long-term unemployment than prime-age workers in the apparel, leather, stone, clay, and glass industries.

Logistic regressions were performed to compare the probability of long-term unemployment with controlling the personal characteristics of the worker across industries. This is done to see how much of the observed industrial disparities in the incidence of longterm unemployment were attributable to the influences of industry-specific employment conditions rather than the heterogeneity of the labor force across industries. Regressions were performed for both the full sample and for the sub-sample for whom the weeks of unemployment was known. Since the results of the regressions based on the two samples were very similar, subsequent discussions will be based mainly on the results obtained from the subsample with the complete information on unemployment.

Age, race, nativity, marital status, household headship, literacy, family size, home

\footnotetext{
15 The incidence of long-term unemployment is reported for each of the 56 industries in Table A-2 of the Appendix.

${ }^{16}$ For the industrial pattern of seasonality in demand for labor, see Lauck and Sydenstricker (1917, 137-152), Kuznets (1933), Lebergott (1964, 168-172), and Engerman and Goldin (1994, 111-116).

${ }^{17}$ Lee (2005) has estimated similar indices for various occupational categories. According to the result, the relative incidence of long-term unemployment of older workers as compared to the young in the same occupation was relatively high for craftsmen, operatives, and salesmen.
} 
ownership, city size, region, and occupation that have been widely employed in previous studies as determining factors of retirement decisions were included in the analysis as variables pertaining to personal characteristics (denoted $X$ in equation 5 ). ${ }^{18}$ Variables on region and the population size of the place were added to consider differences in labor market conditions by location. The percentage of male workers aged 25 to 44 who were unemployed for 24 weeks or longer (Young Unemployed) was included as an indicator of industry-specific labor-market conditions ( $Z$ in equation 5). Inclusion of this variable would allow one to identify the inter-industry differences in labor-market disadvantages associated with aging, eliminating the effects of variations in seasonality and general labor market conditions. The apparel industry was chosen as the omitted category because it had the lowest relative incidence of long-term unemployment.

The first column of Table 2 presents the result for the probability of unemployment for 24 weeks or more (denoted by $P_{\mathrm{U}}$, hereafter). The relatively high incidence of long-term unemployment among older workers employed in several industries remained visible even if personal characteristics were controlled. In particular, the woodworking and primary metals industries stood out as having the highest $P_{\mathrm{U}}$ for older male workers. Printing and fabricated metals also showed particularly high $P_{\mathrm{U}}$, although they missed statistical significance by small margins (p-values are, respectively 0.135 and 0165). The other industries were statistically not different from the apparel industry, the control group.

The estimated effects of individual characteristics are summarized as follows. $P_{U}$ increased with age, as previously reported by Ransom and Sutch (1986) and Margo (1993). Non-white workers were significantly less likely to be unemployed for 24 weeks or more than whites. Family size was negatively related to $P_{U}$. The effects of race and family size could reflect a lower level of reservation wages of non-whites and men with a large family arising from their greater economic needs. Dwellers in a city with 500,000 or more residents were subject to a greater risk of long-term joblessness than individuals who lived in a smaller place. $P_{U}$ among older men was significantly higher in the Western region than in other regions. White collar workers were less likely to be unemployed for a prolonged period

\footnotetext{
${ }^{18}$ Age was included in the regression, implicitly assuming a linear relationship between age and the probability of long-term unemployment. This specification approximates reasonably well the actual link between age and long-term unemployment for men aged 45 and older. The study also used alternative specifications such as dummy variable for each of five-year age intervals and polynomials of age. The estimated coefficients of other variables were not sensitive to the choice of age variable.
} 
than blue collar workers.

The industrial differences in the probability of being unemployed for a shorter period (as offered by the results reported in columns 2 and 3 in Table 2) were much different from the results for long-term unemployment. The more severe labor-market disadvantages associated with aging in the four industries cited above were no longer present when shortterm unemployment was concerned. The probability of unemployment for one week or longer (column 3 of Table 2) was significantly lower in the paper, printing, leather, and fabricated metals industries than those in other industries. It is notable that there was little uniformity in the effect of industry on unemployment across the three regressions. In contrast, the effects of the variables related to personal characteristics were similar across the three specifications. Perhaps, this is the case wherein the risk of losing a job in the first place and the likelihood of finding a new job when unemployed were influenced differently by industrial characteristics.

The patterns of long-term unemployment among older male workers in the industrial era may not simply be explained by inter-industry differences in technological progress, measured by productive efficiency. It is an established fact that the primary and fabricated metals and printing industries experienced major technological innovations during the late nineteenth and early twentieth century. ${ }^{19}$ However, the woodworking industry was not a forerunner in technical progress by the turn of the twentieth century, although it was one of the symbols of the American System in the mid nineteenth century. ${ }^{20}$ Furthermore, the relative incidence of long-term unemployment among older males was not high in a number of Chandlerian industries such as food, chemicals (including petroleum and rubber),

\footnotetext{
${ }^{19}$ In ferrous metals, mass production of steel employing the new Bessemer and open-hearth processes had been established. In nonferrous metals, the adoption of electrolytic refining radically transformed the copper industry (Temin 1964, Chandler 1977). In the printing industry, the introduction of the direct-linecasting machine built by Ottmar Mergenthaler resulted in the replacement of the older, slower workers between 1895 and 1915 (Graebner 1980, 21-23).

${ }^{20}$ Engineers in the early twentieth century believed that the technical progress of the woodworking industry was underdeveloped. For example, B. A. Parks wrote in 1921, "The woodworking industry in one of the oldest industries extant, and yet it has shown the least development and has been slowest to adopt modern principles of manufacturing of any industry of which the writer has knowledge" (Hounshell 1985, p. 126). Chandler (1977, p. 248) reiterated this belief by noting, "By the outbreak of the Civil War, nearly all the machines needed to mass produce wooden products had been perfected.....The speed and volume of throughput increased steadily but slowly.....Total output was increased more by adding men and machines than by continuing technological and organizational innovation."
} 
machinery (including electric machinery), and transportation equipment in which large modern corporations in the United States were heavily concentrated in, and which were regarded as the most capital- and technology-intensive industries of the time. ${ }^{21}$ Thus, it is not sensible to relate the different labor-market status of older workers simply to variations in conventionally-defined technical progress. This calls for looking into a broader range of industrial characteristics representing work environment as well as productive efficiency, which will be discussed in the latter part of this article.

\section{Measuring Industry-Specific Technological Characteristics}

Based upon the industrial statistics reported in the 1909 manufacturing census, the variables that were likely to be related to the employment of older workers were derived. As a measure of labor productivity ( $A$ in equation 5 ), the $\log$ of the value of product per production worker (Productivity) was employed. ${ }^{22}$ Three variables, namely, the size of establishment, choice of input mix, and use of electricity were selected as both indices of technology and measures of work environment. The size of establishment (Firm Size) was measured by the log of the value of total product. The expenditure on non-labor inputs, such as materials and fuels, as percentage of the total costs was employed as the relative importance of non-labor inputs (Non-labor Input). Firm Size might capture a wide range of technical and organizational transformations accompanied by the rise of modern large firms famously documented by Chandler $(1977,1990)$. Inclusion of Non-labor Input allows one to consider the influences of capital-using and material-using biases that were present in the technical progress in the U.S. manufacturing (Cain and Paterson 1981).

${ }^{21}$ In 1917, 122 out of 200 largest industrial enterprises in the United States belonged to these industries. The primary and fabricated metals accounted for another 42 (Chandler 1990, 21). Also, meat-packing (included in the food industry in this study), tobacco, and light machinery have been listed by Chandler (1977) as examples of the industries in which mass-production was first combined with mass-distribution in response to technological changes that made the existing distribution system inadequate.

${ }_{22}$ Wherever possible, this study constructed multiple measures for a particular industrial characteristic. For example, wages per production worker in addition to the value of product per production worker were considered as an index of productivity. As measures of firm size, the value of product, the number of employees, the value of capital per establishment, and the percentage of establishment with values of capitalization of one million dollars or more were considered. The discussions in the paper focus on the results that were obtained based on the measures most strongly correlated with the probability of long-term unemployment of older workers. 
It has been believed that electrification greatly transformed the work environment, as well as the productive efficiency in the U.S. manufacturing in the early twentieth century. ${ }^{23}$ By 1909 , electric drive accounted for $25 \%$ of total capacity for driving machinery. ${ }^{24}$ When electricity was first used for driving machinery in the manufacturing sector in the $1880 \mathrm{~s}$, the major form of driving system was "electric line shaft drive" that replaced a steam engine with one or more electric motors, leaving the power distribution system unchanged. During the first two decades of the twentieth century, this rather primitive system was rapidly replaced by the "group drive" (referring to a system in which a group of machinery was operated by an electric motor), and then by the "unit drive."

On one hand, these changes in power system greatly improved working environment and flexibility of production, which perhaps favorably affected the employment condition of older workers. Absence of the belts, pulleys, and shafts, required for overhead power transmission, led to improvements in illumination, ventilation, and cleanliness. ${ }^{25}$ The group or unit drive enhanced the flexibility of production by allowing the operator to conveniently vary the speed of his or her machine. On the other hand, electrification may have increased the intensity of work. Adoption of the group or unit drive diminished time lost by making it possible to shut down only a single or a small number of machinery rather than the entire factory when a mechanical problem or need for speed change occurred. New technology and scientific management procedure, often believed to be closely related to electrification of production (Whaples 1990b), may have intensified the work as well. To take into account these potential impacts of utilizing electric power, the total horse power driven by electricity per production worker (Electricity) was included in the analysis.

In addition, several indirect measures of hours, intensity, and flexibility of work were employed in the study. First, the percentage of workers employed in an establishment in which the prevailing hours of work was 60 and over (Hours 60 and Over) was considered. Lengthy work was perhaps a major factor that prohibited older workers from continuing to work. A study of micro-census linked to city-level statistics has suggested that older workers

${ }^{23}$ This paragraph is largely based on Devine, Jr. (1983).

${ }^{24}$ During the first decade of the twentieth century, 60 to $70 \%$ of the electric motors in manufacturing plants were powered with electricity generated by the manufacturing establishments themselves.

${ }^{25}$ Devine, Jr. (1983) states: "With unit drive, lights could be provided in places formerly occupied by belts, pulleys, and shafts. Some new buildings incorporated skylights, thus improving ventilation, as well as illumination (p. 365). 
had a higher labor force participation rate when the work week fell (Whaples 1990a).

Second, the percentage of female workers (Female) was considered as a proxy variable of the requirement for physical strength and other types of human capital. Goldin $(1990,81)$ has reported that the manufacturing industries circa 1900 were heavily segregated along the gender lines and that many of the male-intensive industries required substantial amounts of strength or more trainings. Thus, industries with a larger fraction of female employees could have been more favorable for the employment of older male workers. This conjecture seems to be consistent with the fact that Female was positively correlated with some indexes of lower work requirements and higher flexibility. ${ }^{26}$ If female workers were inferior to male workers in the early-twentieth-century manufacturing industries, a higher proportion of women in an industry might indicate a tighter labor market condition that led employers to turn to less-preferred job candidates. However, this conjecture was not supported well by the patterns of correlation between industry variables. ${ }^{27}$

Third, the number of superintendents and managers per 100 production worker (Manager) was included as a proxy variable of work organization and managerial practices. Until the early twentieth century, the overall operation of work-floor in manufacturing units, including decisions on employment, wage, and work-organization, was largely controlled by foremen (Jacoby 1985). According to a Marxist account, companies hired more managers and superintendents in an effort to curb the power of the so-called "craft control" during the late nineteenth and early twentieth century (Lazonick 1990). Thus, Manager could have been related to the development of more formal management of workplaces. Indeed, Manager was positively correlated with some measures of the stability of employment relationship. ${ }^{28}$

\footnotetext{
${ }^{26}$ These correlations have been computed using the industry-level data (including 260 industries) compiled from the 1909 manufacturing census. The percentage of female workers was negatively correlated with wages per worker [correlation coefficient, (denoted $\rho$, hereafter) $=-0.571, \mathrm{p}$-value $(\mathrm{p})$ $<0.0001)$, the capital-labor ratio $(\rho=-0.241, \mathrm{p}<0.0001)$, the value of product per worker $(\rho=-$ $0.209, \mathrm{p}=0.0007$ ), and the percentage of workers employed in an establishment in which the prevailing hours of work was 72 and over $(\rho=-0.0625, p=0.3129)$. On the other hand, it was positively correlated with the percentage of child workers $(\rho=0.640, p<0.0001)$.

${ }^{27}$ The percentage of female workers was weakly but positively correlated with the long-term unemployment rate of younger workers ( $\mathrm{p}$-value $=0.2567$ ), and uncorrelated with the percentage of older workers, another type of marginal workers ( $p$-value $=0.5755)$.

${ }^{28}$ The number of managers per production worker was negatively correlated with the long-term unemployment rate of older workers $(\rho=-0.329, p=0.0333)$ and the long-term unemployment rate of younger workers $(\rho=-0.226, p=0.1307)$. On the other hand, this index was positively correlated to the percentage of workers aged 45 and older.
} 
It is likely that the formalization of workplace management began in more advanced and productive industries. If this was the case, Manager should be positively correlated with measures of technological and managerial development. Indeed, this was the case. It was positively and statistically significantly correlated with capital-labor ratio, electric power use per worker, percentage of expenditure on non-labor inputs, and the value of product per worker. $^{29}$

Finally, the number of clerks per 100 production workers (Clerk) as a measure of production technology and demand for white-collar workers was considered. It has been widely acknowledged that technology and skilled labor are complementary in production. Since white collar workers employed in manufacturing in the early twentieth century were largely skilled workers, a higher proportion of clerks could be regarded as an index of technological progress. In fact, Clerk was positively correlated with measures of higher productivity and more advanced production technology. ${ }^{30}$ Clerks in the early nineteenth century were recruited mostly from a pool of younger and more educated persons. Thus, compared to production workers and older workers who, on the average were less educated, a larger value of Clerk might indicate lower demand for older workers as well.

Table 3 presents the sample means of these industry variables computed for each industry group. The selected measures of work environment were markedly different across industries, even within the group of sectors in which the extent of technical progress was arguably comparable. For example, the chemicals/petroleum/rubber and primary metals industries were among the leading sectors with technical and organizational innovations in that era (Chandler 1977). This reputation was reflected in the result that shows these two industrial groups at or near the top of the orders of Firm Size and Productivity with relatively similar values. However, there were substantial differences between the two industries in terms of Electricity, Hours 60 and Over, Female, Manager, and Clerk. These suggest that technical improvements and organizational innovations in the manufacturing industries,

29 The results for the long-term unemployment rate and for the share of older workers are obtained
by analyzing the industry-level data set (including 56 industries) matched to the 1910 population
census, because information on the age composition of employees and unemployment can be drawn
only from the population census.
30 It was positively correlated with the capital-labor ratio $(\rho=0.285, p<.0001)$, electric power use
per worker $(\rho=0.128, p=0.0389)$, the percentage of expenditure on non-labor inputs $(\rho=0.226, p=$
$0.0002)$, and the average wages $(\rho=0.134, p=0.0301)$. These correlations have been computed
using the industry-level data (including 260 industries) collected from the 1909 manufacturing census. 
though introduced for the same purpose of improving productivity, considerably differed across industries in terms of their features and their influences on the work environment of older workers.

\section{Technology and Employment of Older Workers: Regression Results}

\subsection{Regression Analyses for Long-Term Unemployment}

Logistic regressions were conducted to examine how the variables pertaining to industrial characteristics introduced in the preceding section influenced the probability of long-term unemployment $\left(P_{\mathrm{U}}\right)$. The same variables on personal characteristics employed in the previous regressions reported in Table 2 were included in addition to the industry variables. The results are reported in Table 4 . The regression results for individual variables were remarkably similar to those reported in Table 2

A few variables pertaining to technological and managerial features exerted significant effect on $P_{\mathrm{U}}$. Young Unemployed was positively related to $P_{\mathrm{U}}$. Productivity was negatively associated with $P_{\mathrm{U}}$. On the other hand, Non-labor Input was positively related to $P_{\mathrm{U}}$, whereas, Firm Size and Electricity had no significant effect. This suggests that although more efficient production itself was innocuous for elderly workers, more capital- or materialintensive production technology tended to hurt their labor-market status.

As iterated above, measures of length, intensity, and flexibility of work turned out to be significant predictors of long-term unemployment of older workers. Hours 60 and Over was positively associated with $P_{\mathrm{U}}$, and Female had a negative effect on $P_{\mathrm{U}}$. Clerk also had a strong positive effect on $P_{\mathrm{U}}$. Lastly, more formal employment relationship was perhaps beneficial for older workers, as indicated by the strong positive effect of Manager on $P_{\mathrm{U}}$.

In addition to this baseline regression, similar regressions were performed in which the probabilities of being unemployed for 16 weeks or more, and one week or more were used as dependent variables (columns 2 and 3 of Table 4). A comparison of these results reveals that industry variables had stronger effect on long-term unemployment than on unemployment for a shorter period. In contrast, occupational differences in the probability of unemployment were smaller for lengthier joblessness than for short-term unemployment. This implies that inter-industry differences in technological and managerial characteristics largely affected the degree of difficulty of finding a new job when unemployed rather than 
the risk of losing one's job. ${ }^{31}$

The regression results were generally consistent with the inter-industry differences in the labor-market status of older workers. The particularly higher incidence of long-term unemployment in several industries (Table 2) is explained reasonably well by the results reported in Tables 3 and 4. For example, in case of the primary metals industry, the particularly high value of Hours 60 and Over and low value of Female were perhaps the major reasons that produced the highest incidence of long-term unemployment. ${ }^{32}$ Similarly, the very low values of Productivity and Female, as well as the relatively high value of Hours 60 and Over might at least partially explain the high rate of long-term unemployment among older males employed in the woodworking and lumber industry. A regression result, not reported in the paper, offers that the inter-industry differences in long-term unemployment (presented in Table 2) were no longer present if the variables related to industry-specific technology and work environment were controlled. This indicates that different industrial characteristics captured by the variables considered in this analysis could explain a large fraction of the differences in labor-market status of older males across industries.

\subsection{Regression Analyses for Retirement}

Employing a similar regression model presented in equation 5 (replacing $P_{\mathrm{U}}$ with $P_{R}$, denoting the probability of leaving the labor market between 1900 and 1910), and using a sample of 316 Union Army veterans who were active manufacturing workers in 1900, the study investigated how industrial characteristics affected retirement decisions. Some minor modifications have been made to consider some differences in data. The log value of Union Army pensions was added to consider the previous results that stated that Union Army pensions greatly increased the probability of retirement of veterans (Costa 1998, Lee 1998b,

${ }^{31}$ Similar regressions were conducted separately for the sub-samples, namely, relatively older (ages 55 and older) and middle-age (ages 45 to 54) manufacturing workers. The results of the two regressions, presented in Table A-3 of the Appendix, were generally similar. However, the effects of industry variables on $P_{\mathrm{U}}$ were somewhat larger in magnitude and more significant for older workers than for middle-aged persons. In particular, the effects of Non-labor Input and Clerk were much stronger for older men than younger workers. This indicates that technical changes should have severely hurt the labor-market prospect of older workers than that of younger ones. On the other hand, $P_{\mathrm{U}}$ of a younger worker was strongly influenced by personal characteristics such as age, race, and family size more than that of an older worker.

${ }^{32}$ Hours 60 and Over was 28.312 , as compared to 0.466 in the apparel industry (the control group), the second highest of all industries following the paper industry (33.744). Female was 2.953 as compared to 60.134 in the apparel industry, the fourth from the bottom. 
2005). Since the amount of Union Army pensions was determined based on health status, age, and military experiences, this variable might capture the effects of both non-labor incomes and health. For industry variables, the average of the 1899 and 1909 values were used, wherever possible, to have a closer measure of work environment that the veterans were exposed to during the entire decade under study. For Hours 60 and Over, Manager, and Clerks, which were not available from the 1899 manufacturing census, the 1909 values were used. ${ }^{33}$ Separate regressions were conducted for men aged 55 and older to consider the fact that not many males under age 55 left the labor market for good in the early twentieth century. ${ }^{34}$ The results are reported in Table 5.

In spite of some serious limitations arising from the small and selected sample used for the analysis, the regression results are at least suggestive. The estimated coefficients for Hours 60 and Over, Female, and Manager were all significant, and their signs were the same as those estimated from the regression for long-term unemployment. The parameters for Non-labor Input and Clerk had the same signs, too, although they were statistically insignificant. On the other hand, unlike the results for long-term unemployment, $P_{R}$ was related positively to Firm Size, and negatively to Electricity.

As noted above, the present results are neither representative nor reliable. Moreover, it is difficult to determine whether differences between the two regressions are attributed to employing different measures of labor-market status of older men or to utilizing different samples. Nevertheless, if accepted as real, this result strengthens the argument that length, intensity, and flexibility of work were powerful determinants of labor-market status of older workers. This also suggests that the rise of large corporations had brought about adverse consequences for the employment of elderly workers. The negative relationship between $P_{R}$ and Electricity could be explained by the improvements in the working environment allowed by electrification of the workplace (Devine, Jr. 1983).

\footnotetext{
${ }^{33}$ It is unlikely that hours of work in manufacturing industries changed much between 1899 and 1909 during which nine hours per day was the standard in many industries (Whaples 1990b).

${ }^{34}$ Other minor changes were as follows: The dummy variable for race was eliminated because the sample is composed of white veterans. Taking into account the small sample size and its geographic concentration in the Northeast and Mid West, the dummy variables pertaining to the city size, region, and occupation were reconstructed in ways to represent broader categories of individuals.
} 


\subsection{Productivity Effect versus Matching Effect}

According to the simple model introduced above, each of the industry variables could have affected the probabilities of long-term unemployment and retirement through two different pathways, namely, by changing the quality of matching between the job and the worker (the matching effect) and by changing the size of labor productivity of the industry (the production effect). Since a measure of labor productivity was included, the estimated regression coefficients reported above represented only the matching effect.

To estimate the total effects of the industry variables, regressions were performed from which Productivity was excluded. The results of these regressions are presented in Table A-4 of the Appendix. To compare the matching and productivity effects more conveniently, Table 6 summarizes the results of the two regressions. The differences between the two were calculated and reported in column 3. According to the model, these differences represent the productivity effect. It should be emphasized that this analysis did not intend to accurately decompose the employment effect of technological change. Admittedly, the model and the measures of technology employed in this analysis were too crude to be able to do so. However, this exercise might offer some useful hints as to the question of whether higher productivity generated by technical innovations went hand in hand with improved work environment for older workers.

The results show that the signs of the productivity and matching effects were generally opposite for the industrial variables representing more favorable work environment. This suggests that technical innovations that increased productivity tended to deteriorate the quality of matching among older workers. To take some examples, an increase in Non-labor Input would encourage the employment of older workers by enhancing labor productivity on one hand, but would push elderly workers out of the labor market on the other hand by making their work more demanding or by substituting non-labor inputs for labor. A technological shift represented by an increase in Clerk would bring similar consequences. Shorter prevailing hours, physically less demanding work, and more formalized workplace management, represented by Hours 60 or Over, Female, and Managers respectively, would make work conditions more favorable for older workers although these positive effects were partially offset by lowered Productivity.

Another notable regularity observed in Table 6 is the larger magnitude of the matching effect compared to that of the productivity effect for most of the industry variables. 
In the case of the regression for retirement in particular, the total effect was largely dominated by the matching effect, except for Non-labor Input. Likewise, for long-term unemployment, the size of matching effect was larger in absolute magnitude than that of the productivity effect, except for Firm Size and Non-labor Input. This result indicates that the transformation of the work environment was perhaps a more important pathway than change in productivity since any variation in these industry variables affected the employment of older workers. Putting it differently, an exogenous change in work environment (such as a decrease in Hours 60 and Over) would have a much greater positive direct effect on the employment of older workers than negative indirect effect through reduced productivity.

\section{Conclusions and Implications}

This study has explored how technological, organizational, and managerial changes affected the labor-market status of older male manufacturing workers in the early twentieth century United States. For this purpose, industry-level data have been compiled from the 1899 and 1909 manufacturing censuses and linked to the IPUMS of the 1910 census and a longitudinal sample of Union Army veterans.

The incidence of long-term unemployment among older workers relative to that of prime-age workers, an index of labor-market status of the elderly, was particularly higher in the primary metals, woodworking, printing, and fabricated metals industries than in other sectors. The incidence is true when the personal characteristics of the workers employed in these industries were held constant. Differences in the extent of conventionally defined technical progress did not explain well the industrial differences in the employment status of elderly workers.

It was hypothesized that technological change affected the labor-market status of older men through two different pathways. These are: changing the quality of matching between the job and the worker, referred to as the matching effect and changing labor productivity of the industry or the productivity effect. Based on this model, this study examined how the probabilities of long-term unemployment and retirement among older workers were related to industry variables pertaining to the length, intensity, and flexibility of work, as well as production and managerial efficiency.

The regression results suggested that industrial characteristics that were favorably 
related to the labor-market status of older industrial workers were: higher labor productivity, less capital- or material-intensive production technology, shorter workday, lower intensity of work, greater job flexibility, and more formalized employment relationship. These industrial characteristics accounted for the observed inter-industry differences in the incidence of longterm unemployment. Further analyses showed that the productivity and matching effects were generally opposite in direction for the majority of industrial variables representing more favorable work environment. This suggests that the technical innovations that increased productivity tended to affect negatively the quality of work environment that older workers were exposed to.

The U.S. manufacturing industries experienced tremendous transformations in production technology, work-organization, and managerial practices in the late nineteenth and early twentieth century. Table 7 offers a partial picture of these changes from 1889 to 1919 by providing selected average statistics of the whole manufacturing sector, many of which were considered in this study. It is apparent from the result that firms rapidly grew in size, labor productivity soared, and production became more heavily dependent on materials and energy especially on electric power. It has been well documented that the prevailing hours of work decreased during the period, especially after 1909, although the prevalence of shorter workdays probably came with strengthened intensity of work (Whaples 1990b). In addition, the number of managers per worker and the number of clerks per worker appear to have been increasing. ${ }^{35}$ The proportion of female workers in manufacturing remained stable over the period under investigation in spite of the gradual rise in the LFPR of females.

The results of the study suggest that the transformations in the U.S. industry had probably brought about both favorable and adverse consequences to the labor-market status of older manufacturing workers. On one hand, technical progress and organizational modifications may have improved their employment prospect by improving labor productivity, diminishing hours of work, and formalizing employment relations. On the other hand, some types of technical innovations that led to a more capital- and material-intensive production may have forced older workers out of their jobs by augmenting the requirements for physical strength, mental agility, and ability to acquire new skills. Given that the pace

35 The data this observation was based on were gathered from 1909 and 1919 only. In the 1899 and 1929 manufacturing censuses, the number of managers and clerks are reported in a combined category, making it difficult to calculate their numbers separately. 
and features of technical change differed across industries, and possibly across firms within the same industry, the experiences of individual older workers were presumably highly heterogeneous. In some industries, a few elderly workers probably fell to the state of 'industrial scrap heap,' as claimed by some contemporary critics. However, such a pessimistic view of older workers cannot be generalized for the entire manufacturing industries.

Further questions remain as to which of the two opposite effects were stronger. This is related to the issue of whether technological change actually lowered the overall LFPR of older men within each sector. This is difficult to answer in the light of the evidence offered by this study. This calls for a deeper knowledge of the labor market, technological change, and social progress in that era. Such knowledge offers understanding as to how the environment in workplaces and its relationship to technical progress changed over time. It should also determine how the relationship between productivity improvement and labormarket status of elderly workers changed. ${ }^{36}$ These issues are beyond the scope of the present study. Therefore, these should be considered as future research agenda.

${ }^{36}$ The cross-sectional evidence as of 1910, provided in this study, suggests that it was positive, but it is not warranted that it continued to remain that way. 


\section{References}

Bancroft, G. (1958), The American Labor Force: Its Growth and Changing Composition, New York: John Wiley and Sons.

Boskin, M. J. (1977), "Social Security and Retirement Decisions," Economic Inquiry 15, 1-25.

Cain, Louis, P., and Donald G. Paterson (1981), "Factor Biases and Technical Change in Manufacturing: The American System, 1850-1919," Journal of Economic History 41(2), 341-360.

Carter, Susan, Scott Sigmund Gartner, Michael Haines, Alan Olmstead, Richard Sutch, and Gavin Wright, eds. (2006), Historical Statistics of the United States, Millennial Edition, Vol. 4.

Carter, S. B., and R. Sutch (1996), "Myth of the Industrial Scrap Heap: A Revisionist View of Turnof-the-Century American Retirement," Journal of Economic History 56, 5-38.

Chandler, Alfred D. (1977), The Visible Hand. Cambridge, MA: Belknap.

Chandler, Alfred D. (1990), Scale and Scope. Cambridge, MA: Belknap.

Costa, Dora. L. (1998), The Evolution of Retirement, Chicago; University of Chicago Press.

Devine, Jr., Warren (1983). "From Shafts to Wires: Historical Perspective on Electrification," Journal of Economic History 43 (2), 347-372.

Durand, J. D. (1948), The Labor Force in the United States, 1890-1960, New York: Social Science Research Council.

Engerman, S., and C. Goldin (1994), "Seasonality in Nineteenth Century Labor Markets," In T. Weiss and D. Schaefer. eds., American Economic Development in Historical Perspective. Stanford: Stanford Univ. Press.

Epstein, A. (1928), The Challenge of the Aged, New York: The Vanguard Press.

Friedberg L. (2001), "The Impact of Technological Change on Older Workers: Evidence from Data on Computer Use," NBER Working Paper No. 8297.

Goldin, Claudia (1990), Understanding the Gender Gap, Oxford: Oxford University Press.

Gordon Robert. J. (2000), "Does the 'New Economy' Measure up to the Great Inventions of the Past?" Journal of Economic Perspectives 14, 49-74.

Graebner, W. (1980), A History of Retirement: The Meaning and Function of an American Institution. New Haven: Yale University Press.

Gratton, B. (1986), Urban Elders. Philadelphia: Temple University Press.

Gratton, B. (1988), “The New Welfare State: Social Security and Retirement in 1950," Social Science History 12, 171-196.

Gratton, B. (1996), "The Poverty of Impoverishment Theory: The Economic Well-Being of the Elderly, 1890-1950," Journal of Economic History 56, 39-61.

Gruber J. and Wise D. (1999), Social Security and Retirement around the World, Chicago: University of Chicago Press.

Gruber J. and Wise D. (2004), Social Security Programs and Retirement around the World: Micro Estimation, Chicago: University of Chicago Press.

Haber, C. (1983), Beyond Sixty-Five: The Dilemma of Old Age in America's Past. New York: Cambridge University Press.

Hounshell, David A. (1984), From the American System to Mass Production, 1800-1932, Baltimore: 
Johns Hopkins University Press.

Hurd M. D. (1996), "The Effect of Labor Market Rigidities on the Labor Force Behavior of Older Workers," in Advanced in the Economics of Aging, edited by D Wise, pp 11-59. Chicago: The University of Chicago Press.

Hurd, M. D., and Boskin, M. J. (1984), "The Effect of Social Security on Retirement in the Early 1970s," Quarterly Journal of Economics 99, 767-90.

Hurd M. D and McGarry K. (1993), "The relationship between Job Characteristics and Retirement," NBER Working Paper No. 4558.

Jacoby, Sanford. (1985), Employing Bureaucracy, New York: Columbia University Press.

Keyssar, A. (1986), Out of Work: The First Century of Unemployment in Massachusetts, New York: Cambridge Univ. Press.

Krueger A., and Meyer B. D. (2002), "Labor Supply Effects of Social Insurance," NBER Working Paper No. 9014.

Kuznets, S. (1933), Seasonal Variations in Industry and Trade, New York: National Bureau of Economic Research.

Lazonick, William (1990), Competitive Advantage on the Shop Floor, Harvard University Press.

Lebergott, S. (1964), Manpower in Economic Growth: The American Record since 1800, New York: McGraw-Hill Book Company.

Lauck, W. J., and R. Sydenstricker (1917), Conditions of Labor in American Industries: A Summarization of the Results of Recent Investigations, New York: Funk \& Wagnalls Company.

Lee, Chulhee (1996), "Retirement and Wealth Accumulation in the United States, 1850-1990," Ph.D. Dissertation, University of Chicago.

Lee, Chulhee (1998a), "Rise of the Welfare State and Labor Force Participation of Older Males," American Economic Review 88, 222-226.

Lee, Chulhee (1998b), "Long-Term Unemployment and Retirement in Early-Twentieth-Century America," Journal of Economic History 58, 844-856.

Lee, Chulhee (1999), "Farm Value and Retirement of Farm Owners in Early-Twentieth-Century America," Explorations in Economic History 36, 387-408.

Lee, Chulhee (2002), "Sectoral Shift and Labor Force Participation of Older Males in the United States, 1880-1940," Journal of Economic History 62, 512-523.

Lee Chulhee (2004), "Intra-Household Transfers and Old-Age Security in America, 1890-1950," International Economic Journal 18 (1), 79-102.

Lee Chulhee (2005), "Labor Market Status of Older Males in the United States, 1880-1940," Social Science History 29: 77-105.

Long, C. (1958), The Labor Force Under Changing Income and Employment. Princeton: Princeton Univ. Press.

Margo, Robert. A. (1993), "The Labor Force Participation of Older Americans in 1900: Further Results," Explorations in Economic History 30, 409-423.

Moen, J. R. (1987), Essays on the Labor Force and Labor Force Participation Rates: The United States from 1860 through 1950, Ph.D. Dissertation, The University of Chicago.

Moen, J. R. (1994), "Rural Nonfarm Households: Leaving the Farm and the Retirement of Older 
Men, 1860-1980," Social Science History 18, 55-75.

Mulligan, William, H. (1981), "Mechanization and Work in the American Shoe Industry: Lynn, Massachusetts, 1852-1883," Journal of Economic History 41(1), 59-63.

Parsons, D. O. (1980), “The Decline in Male Labor Force Participation," Journal of Political Economy 51, 657-674.

Parsons, D. O. (1991), "Male Retirement Behavior in the United States, 1930-1950," Journal of Economic History 51, 657-674.

Pedersen, H. (1950), "A Cultural Evaluation of the Family Farm Concept," Land Economics 26, 5264.

Quinn, Joseph, Richard Burkhauser, and Daniel Meyers (1990), Passing the Torch: The Influence of Economic Incentives on Work and Retirement, Kalamazoo, MI: Upjohn Institute.

Ransom, R. L. and R. Sutch (1986), "The Labor of Older Americans: Retirement of Men On and Off the Job, 1870-1937," Journal of Economic History 46, 1-30.

Ransom, R. L. and R. Sutch (1995), "The Impact of Aging on the Employment of Men in American Working-Class Communities at the End of the Nineteenth Century," In Kertzer, D., and P. Laslett, eds., Aging in the Past. Berkeley: University of California Press.

Slichter, S. H. (1919), The Turnover of Factory Labor, New York: D. Appleton and Company.

Squier, L. W. (1912), Old Age Dependency in the United States, New York: Macmillan.

Temin, Peter (1964), Iron and Steel in Nineteenth Century America: An Economic Inquiry, MIT.

United Statues Bureau of the Census (1950), 1950 Census of Population Alphabetical Index of Occupations and Industries, Washington DC: GPO.

Whaples, Robert (1990a), "The Shortening of the American Work Week: An Economic and Historical Analysis of Its Context, Causes, and Consequences," Journal of Economic History 51(2), 454-457.

Whaples Robert (1990b), "Winning the Eight-Hour Day, 1909-1919," Journal of Economic History 50, 393-406. 
Table 1

Incidence of Long-term Unemployment by Industry in 1910

\begin{tabular}{|c|c|c|c|c|c|}
\hline \multirow[b]{2}{*}{ Industry } & \multicolumn{2}{|c|}{ Age $25-44$} & \multicolumn{2}{|c|}{ Age 45 and Older } & \multirow[b]{2}{*}{$\begin{array}{c}(5) \\
(4) /(2)\end{array}$} \\
\hline & $\begin{array}{c}(1) \\
\text { Number }\end{array}$ & $\begin{array}{c}(2) \\
\text { Long-term } \\
\text { Unemployed }\end{array}$ & $\begin{array}{c}\text { (3) } \\
\text { Number }\end{array}$ & $\begin{array}{c}(4) \\
\text { Long-term } \\
\text { Unemployed }\end{array}$ & \\
\hline (20) Food & 1023 & 1.08 & 4990 & 1.63 & 1.51 \\
\hline (21) Tobacco & 231 & 1.30 & 131 & 1.53 & 1.18 \\
\hline (22) Textile & 756 & 1.72 & 383 & 3.66 & 2.13 \\
\hline (23) Apparel & 523 & 4.59 & 200 & 2.50 & 0.54 \\
\hline (24) Lumber/Woodworking & 1479 & 1.56 & 630 & 3.49 & 2.24 \\
\hline (25) Furniture & 271 & 2.58 & 119 & 2.52 & 0.98 \\
\hline (26) Paper & 181 & 1.10 & 70 & 1.43 & 1.30 \\
\hline (27) Printing & 1218 & 2.79 & 504 & 3.97 & 1.42 \\
\hline (28-30) Chemical/Petroleum/ Rubber & 364 & 1.37 & 152 & 1.32 & 0.96 \\
\hline (31) Leather & 479 & 3.76 & 260 & 2.69 & 0.72 \\
\hline (32) Stone/ Clay/ Glass & 685 & 3.21 & 268 & 1.87 & 0.58 \\
\hline (33) Primary Metals & 1325 & 5.36 & 438 & 8.22 & 1.53 \\
\hline (34) Fabricated Metals & 807 & 2.60 & 321 & 4.36 & 1.68 \\
\hline (35-36) Machinery & 824 & 2.79 & 391 & 2.30 & 0.82 \\
\hline (37) Transportation Equipments & 773 & 4.27 & 297 & 4.04 & 0.95 \\
\hline (38) Instruments & 56 & 3.57 & 32 & 3.13 & 0.88 \\
\hline (39) Miscellaneous/Unclassified & 263 & 1.90 & 146 & 3.42 & 1.80 \\
\hline (20-39) All Industries & 10,941 & 2.82 & 4666 & 3.44 & 1.22 \\
\hline
\end{tabular}

Source: IPUMS of the 1910 Census.

Note: Two-digit Standard Industrial Classification code is given in parentheses. 
Table 2

Logistic Regressions: Industrial Differences in the Probability of Long-Term Unemployment in 1910 Male Manufacturing Workers Aged 45 and Older

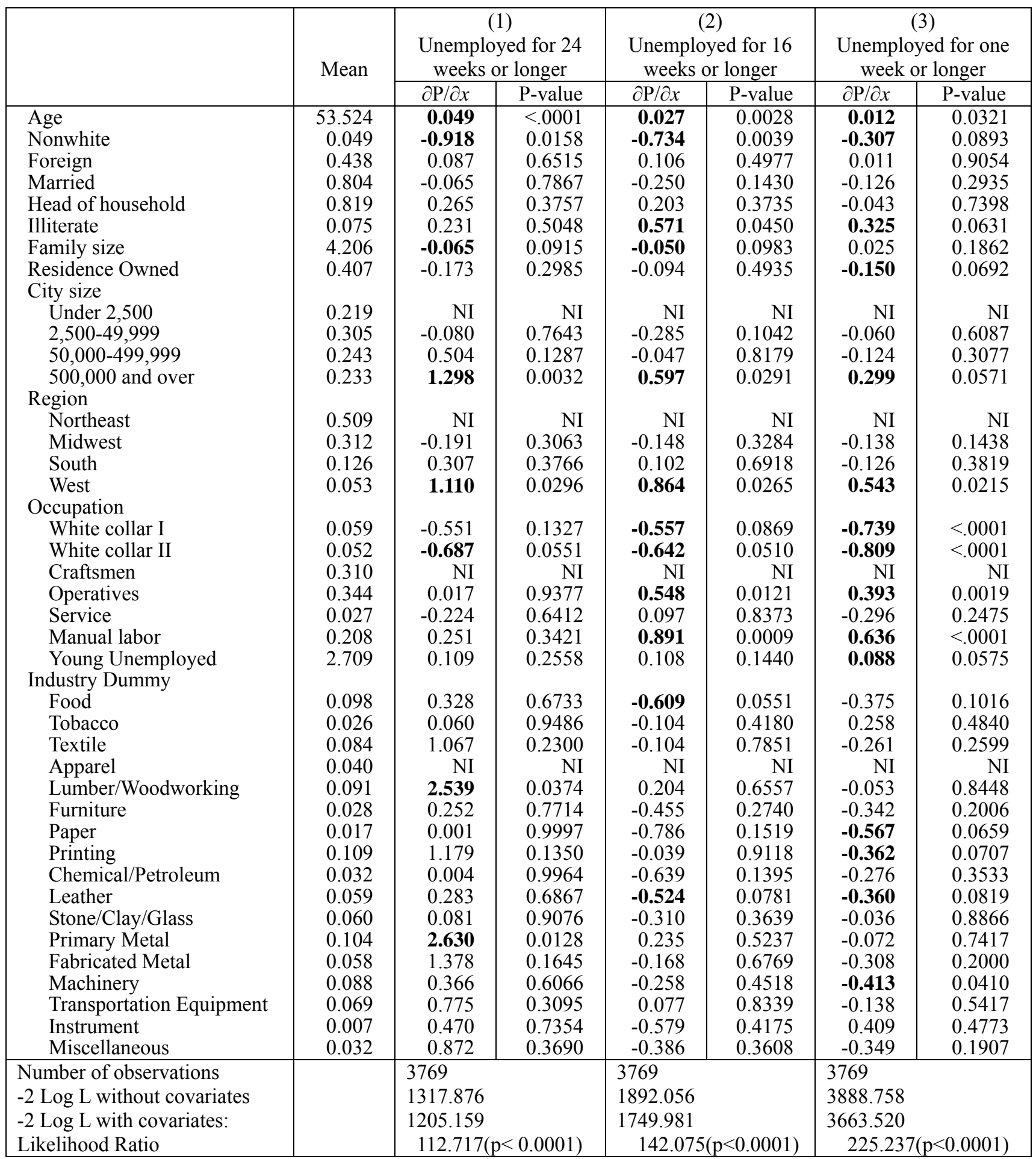

Source: IPUMS of the 1910 census linked to the published 1909 manufacturing census.

Note: The dependent variable for each regression is one if the person was unemployed for 24 weeks or longer during the year prior to the enumeration of the 1910 census, and zero, otherwise. The mean of the dependent variable is 0.042 for (1), 0.069 for (2), and 0.211 for (3). The sample was limited to individuals for whom the number of weeks unemployed was reported. Statistically significant variables are given in bold numbers. 
Table 3

Sample Means of Industrial Characteristics by Industry Group

\begin{tabular}{|c|c|c|c|c|c|c|c|c|c|}
\hline Industry & $\mathrm{N}$ & Firm Size & Productivity & $\begin{array}{l}\text { Non-labor } \\
\text { Input }\end{array}$ & Electricity & $\begin{array}{l}\text { Hours } 60 \\
\text { and Over }\end{array}$ & Female & Manager & Clerk \\
\hline (20) Food & 485 & 11.654 & 9.039 & 92.141 & 0.975 & 22.390 & 11.214 & 3.036 & 13.385 \\
\hline (21) Tobacco & 131 & 10.103 & 7.747 & 81.049 & 0.067 & 0.419 & 48.218 & 1.300 & 4.966 \\
\hline (22) Textile & 361 & 12.618 & 7.530 & 77.765 & 0.514 & 8.566 & 43.728 & 0.770 & 1.984 \\
\hline (23) Apparel & 200 & 11.233 & 7.734 & 78.671 & 0.124 & 0.466 & 60.148 & 1.085 & 8.041 \\
\hline (24) Lumber/Woodworking & 435 & 10.207 & 7.396 & 69.760 & 0.201 & 10.451 & 2.818 & 1.681 & 3.072 \\
\hline (25) Furniture & 119 & 11.047 & 7.549 & 71.923 & 0.393 & 0.196 & 4.330 & 1.765 & 6.237 \\
\hline (26) Paper & 70 & 12.415 & 8.002 & 81.938 & 1.479 & 33.744 & 18.731 & 1.605 & 4.893 \\
\hline (27) Printing & 504 & 9.995 & 7.874 & 72.941 & 0.880 & 0.269 & 22.399 & 3.005 & 20.619 \\
\hline (28-30) Chemical/Petroleum/Rubber & 151 & 12.365 & 8.666 & 90.432 & 1.176 & 15.061 & 10.687 & 2.665 & 13.730 \\
\hline (31) Leather & 260 & 12.057 & 7.973 & 82.040 & 0.311 & 0.155 & 25.120 & 1.509 & 6.385 \\
\hline (32) Stone/Clay/Glass & 268 & 10.408 & 7.278 & 58.623 & 1.011 & 11.473 & 2.420 & 1.965 & 3.985 \\
\hline (33) Primary Metals & 438 & 13.534 & 8.188 & 81.374 & 2.287 & 28.312 & 2.953 & 1.478 & 6.573 \\
\hline (34) Fabricated Metals & 265 & 11.643 & 8.092 & 79.424 & 0.672 & 13.361 & 7.036 & 1.986 & 10.056 \\
\hline (35-36) Machinery & 391 & 11.642 & 7.767 & 73.135 & 1.136 & 0.799 & 5.324 & 2.159 & 10.337 \\
\hline (37) Transportation Equipments & 297 & 11.528 & 7.528 & 65.581 & 0.725 & 5.798 & 0.542 & 1.645 & 5.297 \\
\hline (38) Instruments & 28 & 12.229 & 7.258 & 61.792 & 0.279 & 0.970 & 45.034 & 1.021 & 4.428 \\
\hline (39) Miscellaneous/Unclassified & 146 & 11.067 & 7.729 & 75.124 & 0.327 & 4.578 & 24.689 & 1.565 & 8.297 \\
\hline (20-39) All Industries & 4549 & 11.470 & 7.908 & 76.648 & 0.835 & 9.942 & 16.041 & 1.932 & 8.700 \\
\hline
\end{tabular}

Source: IPUMS of the 1910 census linked to industry-level data compiled from the published report of the 1909 manufacturing census.

Note: See text for definition of variable. N denotes the number of men aged 45 and older included in the IPUMS of the 1910 census who were employed in the given manufacturing industry. 
Table 4

Logistic Regressions: Industrial Characteristics and the Probability of Long-Term Unemployment Male Manufacturing Workers Aged 45 and Older

\begin{tabular}{|c|c|c|c|c|c|c|c|}
\hline & \multirow[t]{2}{*}{ Mean } & \multicolumn{2}{|c|}{$\begin{array}{c}\text { (1) } \\
\text { Unemployed for } 24 \\
\text { weeks or longer }\end{array}$} & \multicolumn{2}{|c|}{$\begin{array}{c}\text { (2) } \\
\text { Unemployed for } 16 \\
\text { weeks or longer }\end{array}$} & \multicolumn{2}{|c|}{$\begin{array}{c}(3) \\
\text { Unemployed for one } \\
\text { week or longer }\end{array}$} \\
\hline & & $\partial \mathrm{P} / \partial x$ & P-value & $\partial \mathrm{P} / \partial x$ & P-value & $\partial \mathrm{P} / \partial x$ & P-value \\
\hline \multicolumn{8}{|l|}{ Individual Variables } \\
\hline Age & 53.524 & 0.050 & $<.0001$ & 0.026 & 0.0032 & 0.012 & 0.0429 \\
\hline Nonwhite & 0.049 & -0.979 & 0.0153 & -0.739 & 0.0034 & -0.296 & 0.1031 \\
\hline Foreign & 0.438 & 0.114 & 0.5595 & 0.134 & 0.3957 & 0.007 & 0.9418 \\
\hline Married & 0.804 & -0.106 & 0.6495 & -0.241 & 0.1215 & -0.131 & 0.2726 \\
\hline Head of household & 0.819 & 0.301 & 0.3195 & 0.223 & 0.3296 & -0.031 & 0.8112 \\
\hline Illiterate & 0.075 & 0.259 & 0.4600 & 0.638 & 0.0283 & 0.345 & 0.0495 \\
\hline Family size & 4.206 & -0.061 & 0.1132 & -0.045 & 0.1320 & 0.025 & 0.1777 \\
\hline Residence Owned & 0.407 & -0.168 & 0.3115 & -0.090 & 0.5132 & -0.142 & 0.0865 \\
\hline \multicolumn{8}{|l|}{ City size } \\
\hline Under 2,500 & 0.219 & NI & NI & NI & NI & NI & NI \\
\hline $2,500-49,999$ & 0.305 & -0.101 & 0.6990 & -0.297 & 0.0848 & -0.071 & 0.5425 \\
\hline $50,000-499,999$ & 0.243 & 0.490 & 0.1365 & -0.053 & 0.0739 & -0.118 & 0.3342 \\
\hline 500,000 and over & 0.233 & 1.248 & 0.0040 & 0.585 & 0.0305 & 0.346 & 0.0301 \\
\hline \multicolumn{8}{|l|}{ Region } \\
\hline Northeast & 0.509 & $\mathrm{NI}$ & NI & NI & NI & NI & NI \\
\hline Midwest & 0.312 & -0.198 & 0.2829 & -0.149 & 0.3215 & -0.107 & 0.2591 \\
\hline South & 0.126 & 0.422 & 0.2365 & 0.210 & 0.4312 & -0.082 & 0.5749 \\
\hline West & 0.053 & 1.209 & 0.0193 & 0.982 & 0.0135 & 0.551 & 0.0192 \\
\hline \multicolumn{8}{|l|}{ Occupation } \\
\hline White collar I & 0.059 & -0.512 & 0.1757 & -0.544 & 0.0979 & -0.728 & $<.0001$ \\
\hline White collar II & 0.052 & -0.665 & 0.0708 & -0.632 & 0.0574 & -0.805 & $<.0001$ \\
\hline Craftsmen & 0.310 & NI & NI & NI & NI & NI & NI \\
\hline Operatives & 0.344 & 0.044 & 0.8383 & 0.518 & 0.0152 & 0.450 & 0.0004 \\
\hline Service & 0.027 & -0.166 & 0.7375 & 0.130 & 0.7853 & -0.287 & 0.2638 \\
\hline Manual labor & 0.208 & 0.335 & 0.2166 & 0.926 & 0.0006 & 0.683 & $<.0001$ \\
\hline \multicolumn{8}{|l|}{ Industry Variables } \\
\hline Young Unemployed & 2.709 & 0.172 & 0.0239 & 0.200 & 0.0004 & 0.119 & 0.0005 \\
\hline Firm Size & 11.516 & -0.039 & 0.7517 & -0.067 & 0.4949 & -0.071 & 0.2285 \\
\hline Productivity & 7.900 & -0.899 & 0.0036 & -0.663 & 0.0418 & 0.009 & 0.9745 \\
\hline Non-labor Input & 76.515 & 0.095 & 0.0175 & 0.028 & 0.2835 & -0.015 & 0.2717 \\
\hline Electricity & 0.850 & -0.176 & 0.4232 & -0.059 & 0.7509 & -0.097 & 0.3604 \\
\hline Hours 60 and Over & 9.886 & 0.024 & 0.0470 & 0.012 & 0.2132 & 0.017 & 0.0015 \\
\hline Female & 15.891 & -0.032 & 0.0008 & -0.015 & 0.0354 & 0.002 & 0.6753 \\
\hline Manager & 1.898 & -0.560 & 0.0049 & -0.467 & 0.0048 & -0.221 & 0.0215 \\
\hline Clerks & 8.559 & 0.155 & 0.0007 & 0.092 & 0.0041 & 0.021 & 0.2001 \\
\hline $\begin{array}{l}\text { Number of observations } \\
-2 \text { Log L w/o covariates } \\
-2 \text { Log L with covariates: } \\
\text { Likelihood Ratio }\end{array}$ & & \multicolumn{2}{|c|}{$\begin{array}{l}3769 \\
1317.876 \\
1206.352 \\
111.5239(\mathrm{p}=0.0002)\end{array}$} & \multicolumn{2}{|c|}{$\begin{array}{l}3769 \\
1892.056 \\
1755.332 \\
136.725(\mathrm{p}<0.0001)\end{array}$} & \multicolumn{2}{|c|}{$\begin{array}{l}3769 \\
3888.758 \\
3666.221 \\
222.5366(\mathrm{p}<0.0001)\end{array}$} \\
\hline
\end{tabular}

Source: IPUMS of the 1910 census linked to the published 1909 manufacturing census.

Note: The dependent variable for each regression is one if the person was unemployed for 24 weeks or longer during the year prior to the enumeration of the 1910 census, and zero, otherwise. The sample was limited to individuals for whom the number of weeks unemployed is reported. Statistically significant variables are given in bold numbers. 
Table 5

Logistic Regressions: Industrial Characteristics and the Probability of Retirement between 1900 and 1910 Union Army Veterans Aged 45 and Older

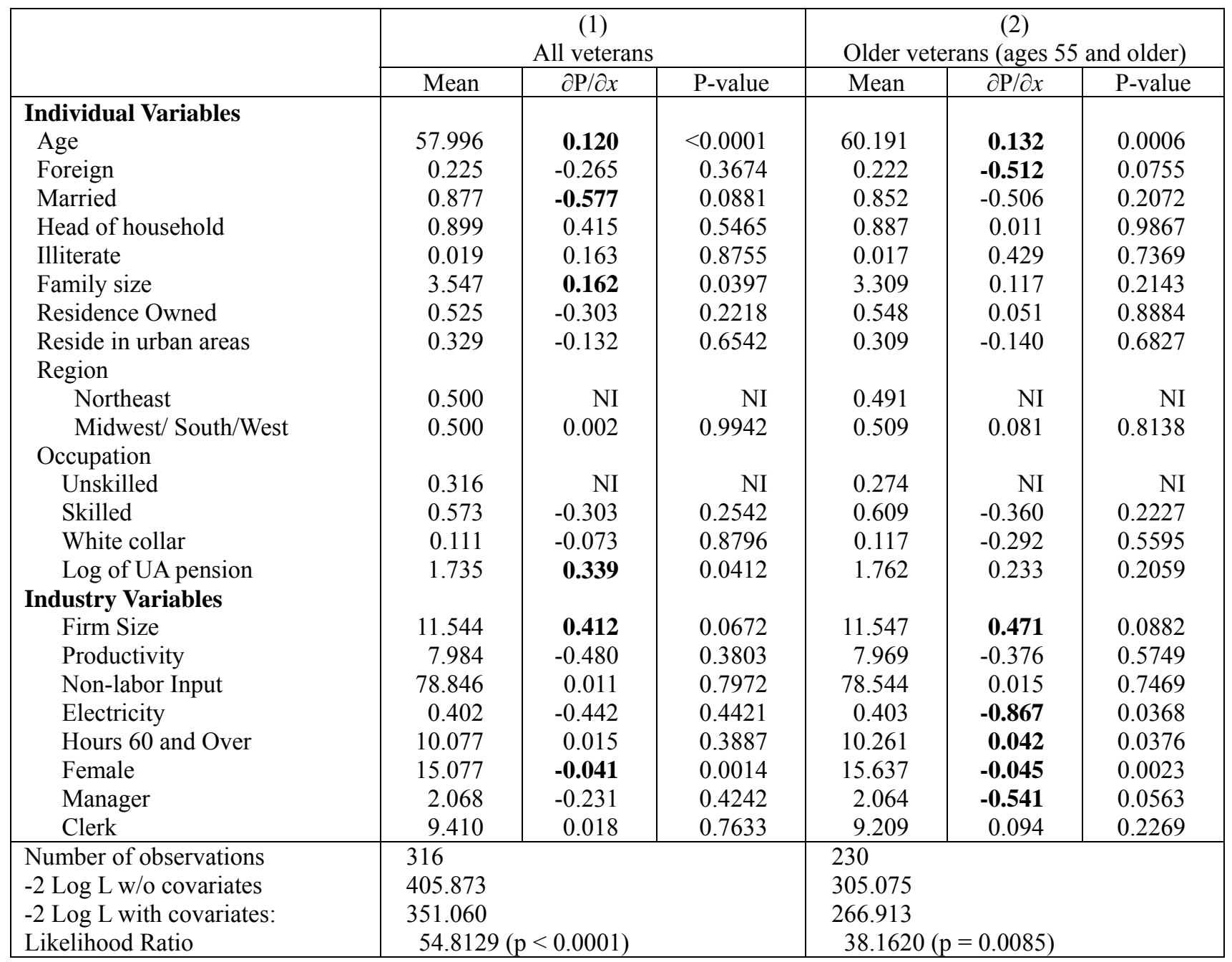

Source: Longitudinal sample of Union Army veterans linked to 1900 and 1910 censuses, and published 1899 and 1909 manufacturing censuses.

Note: The dependent variable for each regression is one if the person was not gainfully employed when the 1910 census was enumerated, and zero, otherwise. The sample is limited to individuals for who were gainfully employed in 1900. The average of the 1899 and 1909 values were used for the following industry variables: Productivity, Nonlabor Input, Electricity, and Female; the values for 1909 were used for the following industry variables: Hours 60 and Over, Manager, and Clerk. Statistically significant variables are given in bold numbers. 
Table 6

Comparison of the Matching Effect and the Productivity Effect

\begin{tabular}{|l|c|c|c|c|c|c|}
\hline & \multicolumn{3}{|c|}{ Long-Term Unemployment } & \multicolumn{3}{c|}{ Retirement } \\
\cline { 2 - 7 } & $(1)$ & $\begin{array}{c}(2) \\
\text { Tatching }\end{array}$ & $\begin{array}{c}(3) \\
\text { Productivity }\end{array}$ & $\begin{array}{c}\text { (4) } \\
\text { Total }\end{array}$ & $\begin{array}{c}\text { (5) } \\
\text { Matching }\end{array}$ & $\begin{array}{c}(6) \\
\text { Productivity }\end{array}$ \\
\hline Firm Size & -0.119 & -0.039 & -0.080 & 0.415 & $\mathbf{0 . 4 7 1}$ & -0.056 \\
Non-labor Input & -0.001 & $\mathbf{0 . 0 9 5}$ & -0.106 & -0.007 & 0.015 & -0.022 \\
Electricity & -0.082 & -0.442 & 0.360 & $\mathbf{- 0 . 8 7 0}$ & $\mathbf{- 0 . 8 6 7}$ & -0.003 \\
Hours 60 and Over & $\mathbf{0 . 0 2 2}$ & $\mathbf{0 . 0 2 4}$ & -0.002 & $\mathbf{0 . 0 3 9}$ & $\mathbf{0 . 0 4 2}$ & -0.003 \\
Female & $\mathbf{- 0 1 2}$ & $\mathbf{- 0 . 0 3 2}$ & 0.020 & $\mathbf{- 0 . 0 4 2}$ & $\mathbf{- 0 . 0 4 5}$ & 0.003 \\
Manager & $\mathbf{0 . 4 8 8}$ & $\mathbf{- 0 . 5 6 0}$ & 0.072 & $\mathbf{- 0 . 5 4 6}$ & $\mathbf{- 0 . 5 4 1}$ & -0.005 \\
Clerk & $\mathbf{0 . 0 7 4}$ & $\mathbf{0 . 1 5 5}$ & -0.081 & 0.087 & 0.094 & -0.007 \\
\hline
\end{tabular}

Sources: Columns (1), (2), (4), and (5) were drawn from, respectively, regression (1) of Appendix Table 4, regression (1) of Table 4, regression (2) of Table 5, and regression (2) of Appendix Table 4; Column (3) = (1) - (2); Column (6) $=(4)-(5)$.

Note: "Total" refers the total effect of each industry variable on the dependent variable; "matching" denotes the effect of each industry variable on the dependent variable through changing quality of matching between the job and the worker; "Productivity" stands for the effect of each industry variable on the dependent variable through changing the labor productivity of the industry. See equation (4) and related text for more detailed explanations. Statistically significant variables are given in bold numbers. 
Table 7

Changes in Selected Average Characteristics of Manufacturing Industries, 1889-1929

\begin{tabular}{|lrrrrr|}
\hline \hline \multicolumn{1}{c}{ Industrial Characteristics } & \multicolumn{1}{c}{1889} & 1899 & 1909 & 1919 & 1929 \\
\hline (1) Value of capital per establishment (dollar) & 18,359 & 19,165 & 68,636 & 153,228 \\
(2) Value of product per establishment(dollar) & 26,370 & 25,386 & 76,993 & 215,157 & 333,879 \\
(3) Value of product per worker (dollar) & 1,989 & 2,450 & 3,125 & 6,862 & 7,969 \\
(4) Expenses on materials / Wages & 2.26 & 3.16 & 3.54 & 3.55 & 3.32 \\
(5) Power per 100 workers (horse power) & 140 & 218 & 288 & 333 & 491 \\
(6) Share of Electric power (percent) & & 4.8 & 25.4 & 55.0 & 82.3 \\
(7) Share of Female workers (percent) & 19.5 & 20.0 & 20.6 & 20.1 & 21.0 \\
(8) Managers per 100 worker & & & 2.0 & 3.1 & 11.4 \\
(9) Clerks per 100 worker & & & 8.7 & 14.5 & 15.4 \\
(10) Managers \& clerks per 100 worker & & 7.5 & 10.7 & & 14.5 \\
\hline
\end{tabular}

Source: Calculated from published manufacturing censuses of 1889, 1899, 1909, 1919, and 1929, except for (5) and (6) that were drawn from Carter et al. (2006), Table Dd848-853. 
Appendix Table A-1

Industry Reclassifications for Matching the 1910 Population Census to the 1909 Manufacturing Census

\begin{tabular}{|c|c|c|c|}
\hline Industries in Population Census & $\begin{array}{c}\text { Number of } \\
\text { Establishments } \\
\end{array}$ & $\begin{array}{c}\text { Number of } \\
\text { Wage Earners } \\
\end{array}$ & Industries in Manufacturing Census \\
\hline Sawmills, planing mills, and mill work & 40671 & 826978 & Lumber and timber products \\
\hline Miscellaneous wood products & 4033 & 59189 & $\begin{array}{l}\text { Baskets, and rattan and willow ware } \\
\text { Boxes, cigar } \\
\text { Cooperage and wooden goods, not elsewhere } \\
\quad \text { specified } \\
\text { Lasts } \\
\text { Looking-glass and picture frames } \\
\text { Wood carpet } \\
\text { Wood preserving } \\
\text { Wood, turned and carved }\end{array}$ \\
\hline Furniture and fixtures & 4453 & 148451 & $\begin{array}{l}\text { Furniture and refrigerators } \\
\text { Mattresses and spring beds } \\
\text { Show cases } \\
\text { Window shades and fixtures }\end{array}$ \\
\hline Glass and glass products & 1094 & 88222 & $\begin{array}{l}\text { Glass } \\
\text { Glass, cutting, staining, and ornamenting } \\
\text { Mirrors }\end{array}$ \\
\hline $\begin{array}{l}\text { Cement, concrete, gypsum, and plaster } \\
\text { products }\end{array}$ & 4625 & 61338 & $\begin{array}{l}\text { Artificial stone } \\
\text { Cement } \\
\text { Lime } \\
\text { Wall plaster }\end{array}$ \\
\hline Structural clay products & 4263 & 91615 & $\begin{array}{l}\text { Brick and tile } \\
\text { Crucibles }\end{array}$ \\
\hline Pottery and related prods & 862 & 53331 & $\begin{array}{l}\text { China decorating } \\
\text { Pottery, terra-cotta, and fire-clay products }\end{array}$ \\
\hline $\begin{array}{l}\text { Miscellaneous nonmetallic mineral and } \\
\text { stone products }\end{array}$ & 5491 & 78086 & $\begin{array}{l}\text { Emery and other abrasive wheels } \\
\text { Kaolin and ground earths } \\
\text { Marble and stone work } \\
\text { Sand and emery paper and cloth } \\
\text { Statuary and art goods } \\
\text { Steam packing }\end{array}$ \\
\hline $\begin{array}{l}\text { Blast furnaces, steel workers, and rolling } \\
\text { mills }\end{array}$ & 731 & 336106 & $\begin{array}{l}\text { Galvanizing } \\
\text { Iron and steel, blast furnaces } \\
\text { Iron and steel, steel works and rolling mills } \\
\text { Tin plate and terneplate }\end{array}$ \\
\hline Other primary iron and steel industries & 385 & 25899 & $\begin{array}{l}\text { Horseshoes, not made in steel works or rolling } \\
\text { mills } \\
\text { Iron and steel, bolts, nuts, washers, and rivets, } \\
\text { not made in steel works or rolling mills } \\
\text { Iron and steel, doors and shutters } \\
\text { Iron and steel forgings }\end{array}$ \\
\hline
\end{tabular}




\begin{tabular}{|c|c|c|c|}
\hline & & & $\begin{array}{l}\text { Iron and steel, nails and spikes, cut and wrought, } \\
\text { including wire nails, not made in steel works } \\
\text { or rolling mills }\end{array}$ \\
\hline \multirow[t]{2}{*}{ Primary nonferrous industries } & 5725 & 146244 & $\begin{array}{l}\text { Babbitt metal and solder } \\
\text { Brass and bronze products } \\
\text { Copper, tin, and sheet-iron products } \\
\text { Gold and silver, leaf and foil } \\
\text { Gold and silver, reducing and refining, not from } \\
\text { the ore } \\
\text { Lead, bar, pipe, and sheet } \\
\text { Smelting and refining, copper } \\
\text { Smelting and refining, lead } \\
\text { Smelting and refining, zinc } \\
\text { Smelting and refining, not from the ore }\end{array}$ \\
\hline & 1537 & 23336 & Jewelry \\
\hline Fabricated steel products & 4664 & 173083 & $\begin{array}{l}\text { Cuttery and tools, not elsewhere specified } \\
\text { Electroplating } \\
\text { Enameling and japanning } \\
\text { Engravers' materials } \\
\text { Engraving and diesinking } \\
\text { Files } \\
\text { Firearms and ammunition } \\
\text { Gas, illuminating and heating } \\
\text { Safes and vaults } \\
\text { Saws } \\
\text { Screws, wood } \\
\text { Springs, steel, car and carriage } \\
\text { Stoves and furnaces, including gas and oil stoves } \\
\text { Wire } \\
\text { Wirework, including wire rope and cable }\end{array}$ \\
\hline Fabricated nonferrous metal products & 656 & 17875 & $\begin{array}{l}\text { Gas and electric fixtures and lamps and reflectors } \\
\text { Vault lights and ventilators }\end{array}$ \\
\hline Agricultural machinery and tractors & 674 & 56789 & $\begin{array}{l}\text { Agricultural implements } \\
\text { Windmills }\end{array}$ \\
\hline Office and store machines & 176 & 12438 & $\begin{array}{l}\text { Scales and balances } \\
\text { Typewriters and supplies }\end{array}$ \\
\hline Miscellaneous machinery & 14882 & 607867 & $\begin{array}{l}\text { Food preparations } \\
\text { Foundry and machine-shop products } \\
\text { Foundry supplies } \\
\text { Pumps, not including steam pumps } \\
\text { Screws, machine } \\
\text { Type founding and printing materials } \\
\text { Washing machines and clothes wringers }\end{array}$ \\
\hline $\begin{array}{l}\text { Electrical machinery, equipment, and } \\
\text { supplies }\end{array}$ & 1411 & 88451 & $\begin{array}{l}\text { Brushes } \\
\text { Electrical machinery, apparatus, and supplies }\end{array}$ \\
\hline
\end{tabular}




\begin{tabular}{|c|c|c|c|}
\hline & & & Phonographs and graphophones \\
\hline $\begin{array}{l}\text { Motor vehicles and motor vehicle } \\
\text { equipment }\end{array}$ & 743 & 96060 & Automobiles, including bodies and parts \\
\hline Ship and boat building and repairing & 1353 & 43564 & Shipbuilding, including boat building \\
\hline $\begin{array}{l}\text { Railroad and miscellaneous } \\
\text { transportation equipment }\end{array}$ & 7471 & 470911 & $\begin{array}{l}\text { Bicycles, motorcycles, and parts } \\
\text { Carriages and wagons and materials } \\
\text { Cars and general shop construction and repairs } \\
\text { by steam-railroad companies } \\
\text { Cars and general shop construction and repairs } \\
\text { by street-railroad companies } \\
\text { Cars, steam-railroad, not including operations of } \\
\text { railroad companies } \\
\text { Cars, street-railroad, not including operations of } \\
\text { railroad companies } \\
\text { Cash registers and calculating machines } \\
\text { Wheelbarrows }\end{array}$ \\
\hline Professional equipment & 2265 & 49784 & $\begin{array}{l}\text { Dentist's materials } \\
\text { Hosiery and knit goods } \\
\text { Instruments, professional and scientific } \\
\text { Optical goods } \\
\text { Surgical appliances and artificial limbs }\end{array}$ \\
\hline Photographic equipment and supplies & 16 & 353 & Moving pictures \\
\hline $\begin{array}{l}\text { Watches, clocks, and clockwork-operated } \\
\text { devices }\end{array}$ & 120 & 15775 & $\begin{array}{l}\text { Clocks and watches, including cases and } \\
\text { materials }\end{array}$ \\
\hline Miscellaneous manufacturing industries & 4799 & 105545 & $\begin{array}{l}\text { Artificial flowers and feathers and plumes } \\
\text { Artists' materials } \\
\text { Billiard tables and materials } \\
\text { Candles } \\
\text { Carriages and sleds, children's } \\
\text { Coffins, burial cases, and undertakers' goods } \\
\text { Cork, cutting } \\
\text { Fire extinguishers, chemical } \\
\text { Fireworks } \\
\text { Furs, dressed } \\
\text { Hair work } \\
\text { Hand stamps and stencils and brands } \\
\text { Ink, writing } \\
\text { Jewelry and instrument cases } \\
\text { Lapidary work } \\
\text { Models and patterns, not including paper patterns } \\
\text { Musical instruments and materials, not specified } \\
\text { Musical instruments, pianos and organs and } \\
\text { materials } \\
\text { Needles, pins, and hooks and eyes }\end{array}$ \\
\hline
\end{tabular}




\begin{tabular}{|c|c|c|c|}
\hline & & & $\begin{array}{l}\text { Pens, fountain, stylographic, and gold } \\
\text { Pipes, tobacco } \\
\text { Signs and advertising novelties } \\
\text { Silverware and plated ware } \\
\text { Soda-water apparatus } \\
\text { Sporting and athletic goods } \\
\text { Toys and games } \\
\text { Umbrellas and canes } \\
\text { Wool pulling } \\
\text { All other industries }\end{array}$ \\
\hline Meat products & 1641 & 88352 & Slaughtering and meat packing \\
\hline Dairy products & 8736 & 22962 & $\begin{array}{l}\text { Butter, cheese, and condensed milk } \\
\text { Butter, reworking } \\
\text { Dairymen's poulterers', and apiarists' supplies }\end{array}$ \\
\hline $\begin{array}{l}\text { Canning and preserving fruits, } \\
\text { vegetables, and seafoods }\end{array}$ & 3767 & 67219 & Canning and preserving \\
\hline Grain-mill products & 87 & 1930 & $\begin{array}{l}\text { Flax and hemp, dressed } \\
\text { Rice, cleaning and polishing }\end{array}$ \\
\hline Bakery products & 23926 & 84956 & Bread and other bakery products \\
\hline Confectionery and related products & 2017 & 21159 & $\begin{array}{l}\text { Chocolate and cocoa products } \\
\text { Confectionery } \\
\text { Peanuts, grading, roasting, cleansing, and } \\
\text { shelling }\end{array}$ \\
\hline Beverage industries & 7464 & 77288 & $\begin{array}{l}\text { Cordials and sirups } \\
\text { Liquors, distilled } \\
\text { Liquors, malt } \\
\text { Liquors, vinous } \\
\text { Malt } \\
\text { Mineral and soda waters }\end{array}$ \\
\hline $\begin{array}{l}\text { Miscellaneous food preparations and } \\
\text { kindred products }\end{array}$ & 4540 & 61322 & $\begin{array}{l}\text { Baking powders and yeast } \\
\text { Beet sugar } \\
\text { Coffee and spice, roasting and grinding } \\
\text { Flavoring extracts } \\
\text { Glucose and starch } \\
\text { Ice, manufactured } \\
\text { Oleomargarine } \\
\text { Sugar and molasses } \\
\text { Vinegar and cider }\end{array}$ \\
\hline Not specified food industries & 11691 & 41787 & Flour-mill and gristmill products \\
\hline Tobacco manufactures & 15822 & 90417 & Tobacco manufactures \\
\hline $\begin{array}{l}\text { Dyeing and finishing textiles, except knit } \\
\text { goods }\end{array}$ & 426 & 36486 & Dyeing and finishing textiles \\
\hline Carpets, rugs, and other floor coverings & 567 & 21147 & $\begin{array}{l}\text { Carpets and rugs, other than rag } \\
\text { Carpets, rag }\end{array}$ \\
\hline Yarn, thread, and fabric & 3433 & 331283 & $\begin{array}{l}\text { Cotton goods, including cotton small wares } \\
\text { Haircloth } \\
\text { Silk and silk goods, including throwsters } \\
\text { Upholstering materials }\end{array}$ \\
\hline
\end{tabular}




\begin{tabular}{|c|c|c|c|}
\hline & & & $\begin{array}{l}\text { Wool scouring } \\
\text { Woolen, worsted, and felt goods, and wool hats }\end{array}$ \\
\hline Miscellaneous textile mill products & 434 & 24863 & $\begin{array}{l}\text { Cordage and twine and jute and linen goods } \\
\text { Hats, straw } \\
\text { Oilcloth and linoleum } \\
\text { Shoddy } \\
\text { Waste }\end{array}$ \\
\hline Apparel and accessories & 15790 & 224177 & $\begin{array}{l}\text { Clothing, horse } \\
\text { Clothing, men's, buttonholes } \\
\text { Clothing, men's, including shirts } \\
\text { Clothing, women's } \\
\text { Corsets } \\
\text { Fur goods } \\
\text { Furnishing goods, men's } \\
\text { Hat and cap materials } \\
\text { Hats and caps, other than felt, straw, and wool } \\
\text { Hats, fur-felt } \\
\text { Millinery and lace goods }\end{array}$ \\
\hline Misc fabricated textile products & 1273 & 10199 & $\begin{array}{l}\text { Awnings, tents, and sails } \\
\text { Bags, other than paper } \\
\text { Cloth, sponging and refinishing } \\
\text { Flags, banners, regalia, society badges and } \\
\text { emblems } \\
\text { Hammocks } \\
\text { House-furnishing goods, not elsewhere specified }\end{array}$ \\
\hline Pulp, paper, and paper-board mills & 777 & 68497 & Paper and wood pulp \\
\hline Paperboard containers and boxes & 1443 & 22573 & $\begin{array}{l}\text { Boxes, fancy and paper } \\
\text { Fancy articles, not elsewhere specified }\end{array}$ \\
\hline Miscellaneous paper and pulp products & 880 & 22079 & $\begin{array}{l}\text { Bags, paper } \\
\text { Card cutting and designing } \\
\text { Labels and tags } \\
\text { Paper goods, not elsewhere specified } \\
\text { Paper patterns } \\
\text { Pulp goods } \\
\text { Stationery goods, not elsewhere specified } \\
\text { Wall paper }\end{array}$ \\
\hline Printing, publishing, and allied industries & 32014 & 212753 & $\begin{array}{l}\text { Engraving, wood } \\
\text { Photo-engraving } \\
\text { Printing and publishing } \\
\text { Stereotyping and electrotyping }\end{array}$ \\
\hline Drugs and medicines & 3667 & 12141 & $\begin{array}{l}\text { Drug grinding } \\
\text { Patent medicines and compounds and druggists' } \\
\text { preparations }\end{array}$ \\
\hline Paints, varnishes, and related products & 791 & 13207 & Paint and varnish \\
\hline $\begin{array}{l}\text { Miscellaneous chemicals and allied } \\
\text { products }\end{array}$ & 5445 & 152579 & $\begin{array}{l}\text { Blacking and cleansing and polishing } \\
\text { preparations } \\
\text { Bluing }\end{array}$ \\
\hline
\end{tabular}


Appendix Table A-2

Incidence of Long-term Unemployment by Industry in 1910: Original Industry Classification

\begin{tabular}{|c|c|c|c|c|}
\hline Industry & Number & $\begin{array}{c}\% \text { Workers } \\
\text { aged } 45+\end{array}$ & $\begin{array}{c}\text { \% Long-Term } \\
\text { Unemployed, } \\
\text { aged 25-44 }\end{array}$ & $\begin{array}{l}\text { \% Long-Term } \\
\text { Unemployed, } \\
\text { aged } 45+\end{array}$ \\
\hline Logging & $\overline{7776}$ & 25.13 & 2.64 & 1.03 \\
\hline Sawmills, planing mills, and mill work & 1716 & 19.29 & 0.88 & $\underline{4.23}$ \\
\hline Miscellaneous wood products & 352 & 29.55 & 2.60 & 5.77 \\
\hline Furniture and fixtures & 507 & 23.47 & 2.58 & 2.52 \\
\hline Glass and glass products & 277 & 18.77 & 5.07 & 3.85 \\
\hline Cement, concrete, gypsum, and plaster products & 244 & 22.13 & 3.39 & 1.85 \\
\hline Structural clay products & 465 & 17.42 & 2.76 & 0.00 \\
\hline Pottery and related prods & 76 & 28.95 & $\underline{2.78}$ & $\underline{0.00}$ \\
\hline Miscellaneous nonmetallic mineral and stone products & 236 & 25.00 & 2.16 & 3.39 \\
\hline Blast furnaces, steel workers, and rolling mills & 1515 & 19.08 & 6.20 & 8.30 \\
\hline Other primary iron and steel industries & 857 & 17.39 & 3.91 & 8.05 \\
\hline Primary nonferrous industries & 335 & 18.81 & 2.16 & 1.59 \\
\hline Fabricated steel products & 867 & 23.30 & 1.57 & 4.46 \\
\hline Not specified metal industries & 324 & 17.28 & 5.68 & 7.14 \\
\hline Agricultural machinery and tractors & 214 & 36.92 & 2.13 & 1.27 \\
\hline Office and store machines & 69 & 21.74 & $\underline{3.13}$ & $\underline{0.00}$ \\
\hline Miscellaneous machinery & 1077 & 23.03 & 2.68 & 2.42 \\
\hline Electrical machinery, equipment, and supplies & 332 & 14.76 & 3.41 & $\underline{4.08}$ \\
\hline Motor vehicles and motor vehicle equipment & 415 & 13.98 & 1.28 & 1.72 \\
\hline Ship and boat building and repairing & 290 & 26.55 & 3.77 & 0.00 \\
\hline Railroad and miscellaneous transportation equipment & 709 & 22.85 & 6.33 & 6.79 \\
\hline Professional equipment & 34 & 23.53 & $\underline{5.00}$ & \\
\hline Photographic equipment and supplies & 14 & 28.57 & & \\
\hline Watches, clocks, and clockwork-operated devices & 57 & 35.09 & $\underline{3.33}$ & $\underline{5.00}$ \\
\hline Miscellaneous manufacturing industries & 560 & 26.07 & 1.90 & 3.42 \\
\hline Meat products & 382 & 23.56 & 0.99 & 2.22 \\
\hline Dairy products & 243 & 15.64 & 1.43 & $\underline{0.00}$ \\
\hline Canning and preserving fruits, vegetables, and sea foods & 57 & 29.82 & $\underline{3.57}$ & \\
\hline Crain-mill products & 229 & 36.68 & 0.00 & 0.00 \\
\hline Bakery products & 260 & 16.54 & 0.73 & $\underline{6.98}$ \\
\hline Confectionery and related products & 174 & 19.54 & 0.00 & $\underline{2.94}$ \\
\hline Beverage industries & 411 & 31.39 & 0.97 & 0.78 \\
\hline Miscellaneous food preparations and kindred products & 208 & 24.04 & 2.06 & 2.00 \\
\hline Not specified food industries & 13 & 38.46 & & \\
\hline Tobacco manufactures & 478 & 27.41 & 1.30 & 1.53 \\
\hline Knitting mills & 107 & 20.56 & $\underline{2.33}$ & $\underline{4.55}$ \\
\hline Dyeing and finishing textiles, except knit goods & 91 & 25.27 & $\underline{0.00}$ & $\underline{8.70}$ \\
\hline Carpets, rugs, and other floor coverings & 101 & 26.73 & $\underline{4.65}$ & $\underline{3.70}$ \\
\hline Yarn, thread, and fabric & 1227 & 23.63 & $\overline{1.52}$ & 3.45 \\
\hline Miscellaneous textile mill products & 101 & 20.79 & $\underline{2.50}$ & $\underline{0.00}$ \\
\hline Apparel and accessories & 940 & 20.43 & 4.61 & 2.60 \\
\hline
\end{tabular}


Miscellaneous fabricated textile products

Pulp, paper, and paper-board mills

Paperboard containers and boxes

Miscellaneous paper and pulp products

Printing, publishing, and allied industries

Drugs and medicines

Paints, varnishes, and related products

Miscellaneous chemicals and allied products

Petroleum refining

Miscellaneous petroleum and coal products

Rubber products

Leather: tanned, curried, and finished

Footwear, except rubber

Leather products, except footwear

\begin{tabular}{r|r|r|r|}
55 & 14.55 & $\underline{4.17}$ & \\
284 & 20.07 & 1.27 & 1.75 \\
23 & 26.09 & & \\
31 & 22.58 & & \\
2430 & 20.74 & 2.79 & 3.97 \\
35 & 22.86 & & \\
81 & 23.46 & $\underline{4.17}$ & \\
281 & 25.62 & 0.65 & 1.39 \\
105 & 21.90 & 0.00 & $\underline{0.00}$ \\
1 & 1.00 & & \\
164 & 17.68 & 2.33 & $\underline{0.00}$ \\
306 & 21.57 & 5.81 & 1.52 \\
569 & 24.96 & 3.10 & 2.82 \\
147 & 35.37 & 1.52 & 3.85 \\
\hline
\end{tabular}

Source: IPUMS of the 1910 Census.

Note: Estimates of long-term unemployment rate are not given for age-industry cells including less than 20 persons; cells including 20 to 29 persons are marked by underlines. 
Appendix Table A-3

Logistic Regressions: 1910 Industrial Characteristics and the Probability of Long-Term Unemployment For Male Manufacturing Workers Aged 45 and Older by Age

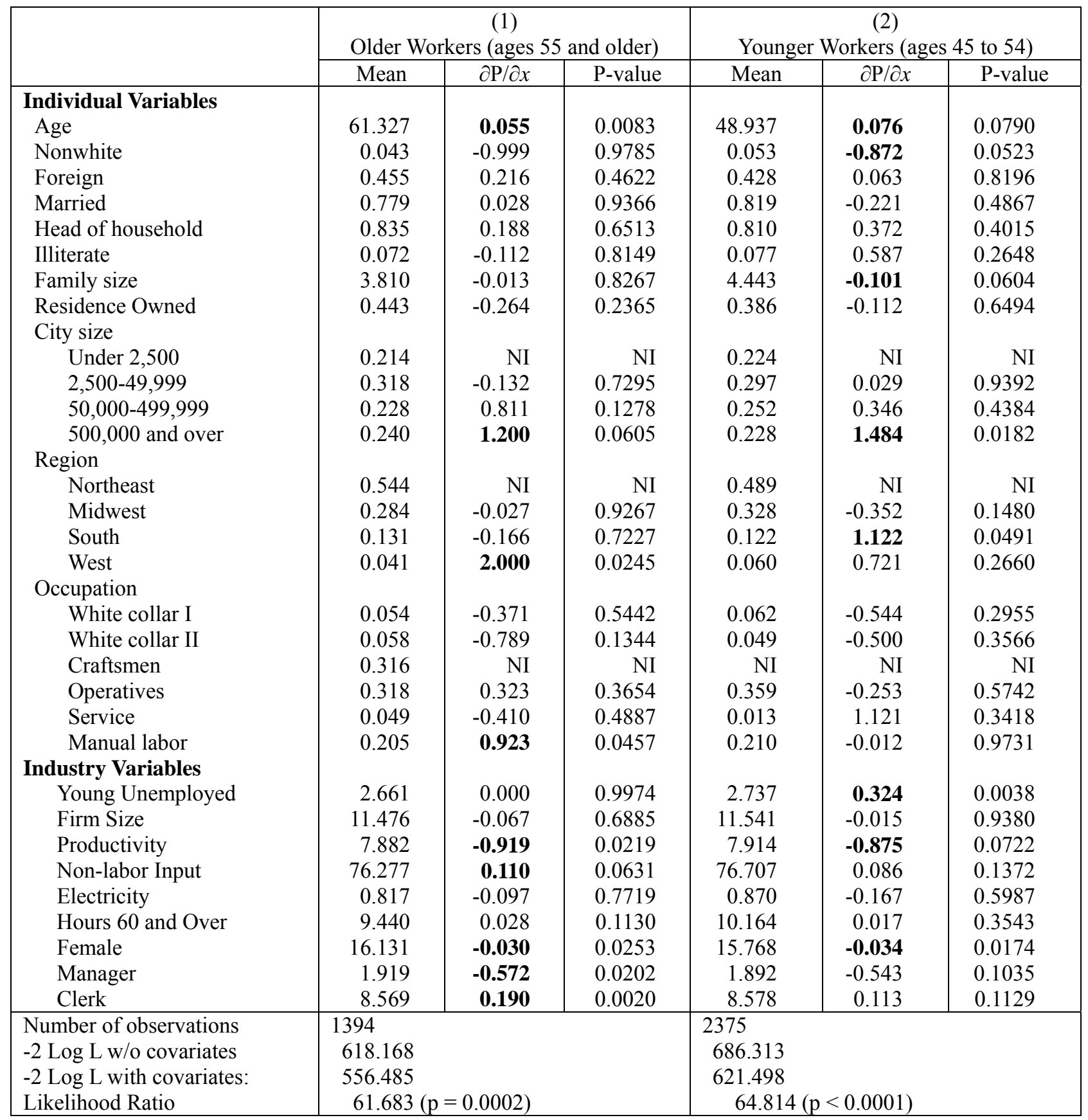

Source: IPUMS of the 1910 census linked to the published 1909 manufacturing census.

Note: The dependent variable for each regression is one if the person was unemployed for 24 weeks or longer during the year prior to the enumeration of the 1910 census, and zero, otherwise. The sample was limited to individuals for whom the number of weeks unemployed was reported. Statistically significant variables are given in bold numbers. 
Appendix Table A-4

Logistic Regressions without Labor Productivity Measure

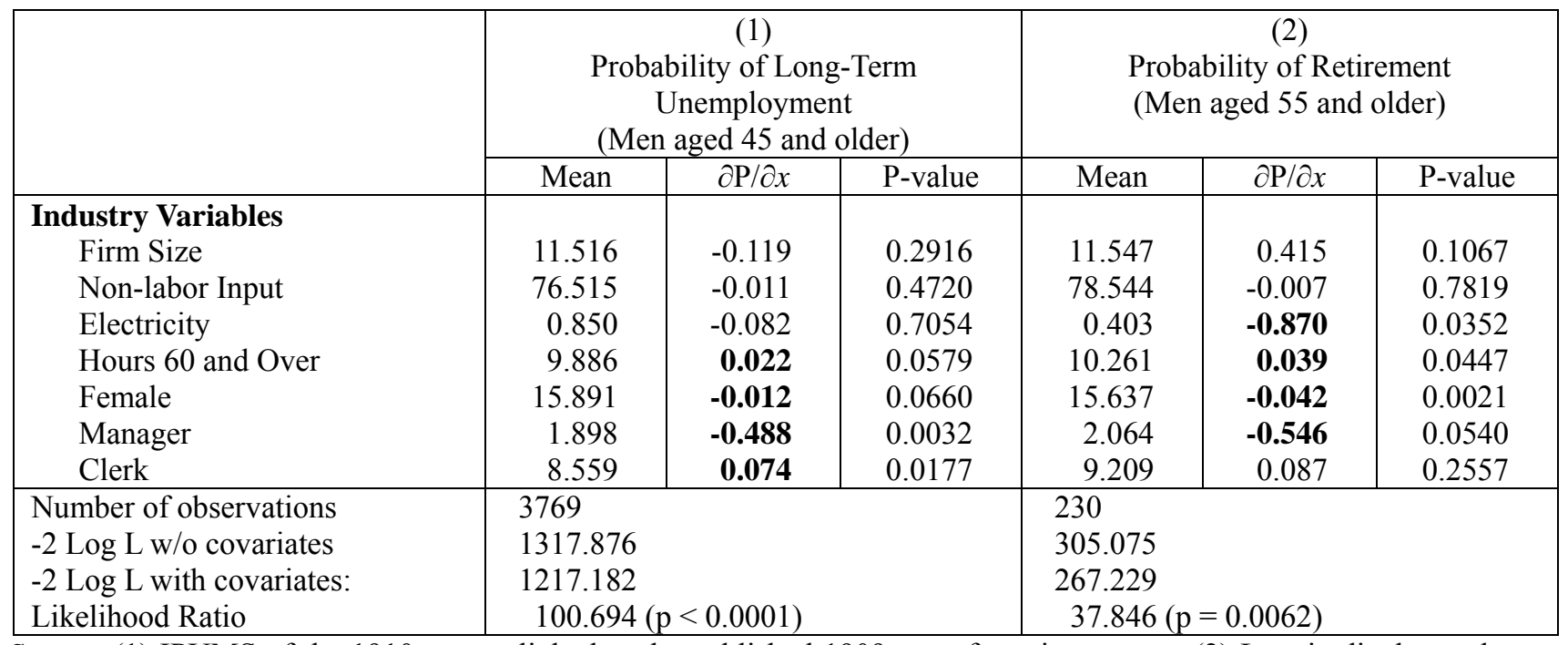

Source: (1) IPUMS of the 1910 census linked to the published 1909 manufacturing census; (2) Longitudinal sample of Union Army veterans linked to 1900 and 1910 censuses, and published 1899 and 1909 manufacturing censuses.

Note: 1. Regression (1): The dependent variable is one if the person was unemployed for 24 weeks or longer during the year prior to the enumeration of the 1910 census, and zero, otherwise. The sample was limited to individuals for whom the number of weeks unemployed is reported. All independent variables used in the regressions reported in Table 4 are included, but the results for individual variables are omitted from this table.

2. Regression (2): The dependent variable is one if the person was not gainfully employed when the 1910 census was enumerated, and zero, otherwise. The sample was limited to individuals for who were gainfully employed in 1900. The average of the 1899 and 1909 values were used for the following industry variables: Productivity, Nonlabor Input, Electricity, and Female; the values for 1909 were used for the following industry variables: Hours 60 and Over, Manager, and Clerk. All independent variables used in the regressions reported in Table 5 were included, but the results for individual variables were omitted from this table. Statistically significant variables are given in bold numbers. 